\title{
COLLECTION ANTHROPOLOGIQUE DU MUSÉUM DE PARIS: \\ ETHNOGRAPHIC PORTRAITS BY JACQUES-PHILIPPE POTTEAU
}

By

Juli Sheptytsky-Zäll

BFA Photography, Toronto, 2007

A thesis project presented to

Ryerson University \& Art Gallery of Ontario

In partial fulfilment of the requirements for the degree of Master of Arts

in the Program of

Photographic Preservation and Collections Management

Toronto, Ontario, Canada, 2009

(C) Juli Sheptytsky-Zäll 2009 
I hereby declare that I am the sole author of this thesis.

I authorize Ryerson University to lend this thesis to other institutions or individuals for the purpose of scholarly research.

I further authorize Ryerson University to reproduce this thesis by photocopying or by other means, in total or in part, at the request of other institutions or individuals for the purpose of scholarly research. 


\begin{abstract}
Jacques-Philippe Potteau, a lesser known photographer and naturalist in nineteenth-century France, produced a series of ethnographic portraits under the title "Collection Anthropologique du Museum de Paris" for the Muséum d'Histoire naturelle in Paris, between 1860 and 1869. This paper investigates a representative set of the series, found at the Art Gallery of Ontario, which has been used as a source of information for looking at the photographer's mode and scope of production.

These ethnographic portraits, made according to conventions of commercial studio portraiture in Second Empire France, were used for the study and classification of man and displayed as specimens in the Anthropology Collection at the Muséum. By looking at the variation between the most formal and the most sterile compositions, the various presentation methods and the labels as a new source of information, Potteau is identified as a photographer who produced work more independently than previously thought.
\end{abstract}


I was introduced to this body of photographs at the Art Gallery of Ontario, where I was completing the second year of my program of study. Maia-Mari Sutnik, the curator of the photography department and Sophie Hackett, assistant curator, who were also two of the faculty members of the program, presented the photographs as an example of the many treasures found in the AGO collection. They were very supportive in my process and provided a number of leads on how to go about researching the set of photographs. Among other faculty members who contributed to this process were, David Harris whose enthusiasm for the material propelled my own interest and Marta Braun, who provided me with a healthy pile of reading material on the topic of photography and anthropology.

My classmates, with whom I shared all my frustrations and small victories, have been a tremendous testament to the value that good colleagueship and even better friendship can harness.

In Paris, the staff of the Bibliothèque national de France at Richelieu was very gracious in letting me handle precious material and answered numerous questions about it to the best of their knowledge. Christine Barthe at the Musée du quai Branly, without knowing it, helped me to find the 'hook' that I'd been searching for since undertaking the project. Her indispensible knowledge led me through a web of unaccounted details, which I would not have been able to decipher alone.

I must also mention the wonderful staff at Harvard University. Particia Kervick at the Peabody Museum Archives was unable to locate the photographs I was looking for in her own collection and put me in touch with David Odo. Professor Odo, who has a mental catalogue of all the material in the anthropology collection at Harvard, pointed me in the direction of the Tozzer Library. Just when I though the trail ran dry, Janet Steins, the associate librarian devoted her time and efforts to helping me find what no one seemed to know was there, an impressive set of the "Collection Anthropologique du Muséum de Paris." Dana Fischer at the Library of the Museum of Comparative Zoology devoted an afternoon to helping me try to track down the provenance of the collection. The expertise and efficiency of all the staff at Harvard has made a lasting impression.

Most of all, I am grateful to my advisors Thierry Gervais and Marta Braun, whose stern and dedicated approach to this project helped to produce a paper that I am proud of. There were many occasions throughout the process when I felt I reached a dead end. Thierry's remarkable mind, which seemed never to stop questioning and drawing connections, was an amusement and an inspiration. Marta's patience in refining the details helped me to see the subject more clearly and better understand my working process.

Thanks You to all those who met me with open doors and open minds. 
Til min elskede søde mand som tror at jeg er den klogeste bjørn i verden. Din støtte holdt mig oppe og jeg håber jeg at kunne være der for dig I dine svære tider.

$$
\text { Tak }
$$


Introduction

Literature Survey

1

7

14

Historical \& Biographical Context

1 | Anthropology and the photographic industry

2 | The Photographers

Methodology - 'reading' anthropological photographs

Scope of the Series

Description of Objects

1 | Presentations - a note on $19^{\text {th }}$ century aesthetics

2 | Content - subject not object

Labels

1 | Labelled Objects - portrait or specimen

2 | Uncut Labels - the in between

Conclusion

Appendices

I Database

II Data Analysis

III List of Images in the AGO collection
14

16

19

24

30

31

36

40

41

45

49

52

57

58

64

Bibliography 
The Art Gallery of Ontario (AGO) has an eclectic collection of photography that amounts to over 60,000 objects. The material represents a range of processes and applications spanning the history of the medium: from photojournalism archives to vernacular three-dimensional objects and photographic artworks. Among this collection is a set of 253 ethnographic portraits, from a larger photographic series titled "Collection Anthropologique du Muséum de Paris" (henceforth Collection Anthropologique). The series created between 1855 and $1869^{1}$ for the Muséum d'Histoire naturelle (Muséum) in Paris included ethnographic portraits, photographs of skulls, photographic reproductions of plaster casts of human heads and drawings made before the invention of photography, among other anthropological images.

Although the exact number of wet-collodion glass plate negatives that comprised the original series is unknown, there were likely well over $1000^{2}$ plates. The original views in the series were made by a number of photographers including, Louis Rousseau, Pierre-Joseph Rossier, and Paul-Émile Miot, but the majority of them is attributed to Jacques-Philippe Potteau. Some images in the series were contributed by other individuals and made by unknown photographers. Potteau made duplicate negatives from these images, which were then included in the series.

The AGO set of images is representative of the ethnographic portraits included in the Collection Anthropologique, as it contains nearly half of the

\footnotetext{
1 These are the earliest and latest dates known, taken from the labels attached to the image mounts and sheets of uncut labels.

2 It is difficult to ascertain what constitutes a complete series, as no original inventory of the Collection Anthropologique exists. Jacques-Philippe Potteau, one of the major contributors to the Collection Anthropologique, made at least 1138 negatives for the Muséum, most of which are known to be part of the series.
} 
approximately $600^{3}$ ethnographic portraits included in the series; 244 of the images are by Potteau, eight by Rossier and one by contributor M. L'abbé Larnandie. The set consists chiefly of pairs of three-quarter-length, frontal and profile portraits of subjects of different ethnicities, printed on albumen, mounted on card stock and labelled on the verso; ten sheets of uncut printed labels also accompany this set. The Collection Anthropologique du Muséum de Paris is a much larger body of work than is presented in this paper. However, this investigation is concerned only with the portraits, which represent the initial (beginning with label number 1 to approximately 300 ) portion of the series. ${ }^{4}$

The ethnographic portraits that are part of the Collection Anthropologique series made by Potteau are unique in comparison to other anthropological images in this vein. There are a number of later photographic projects that emulate this model for making ethnographic portraits (frontal and profile depictions of the sitter, basic subject identification), for example the Collection Anthropologique du Prince Roland Bonaparte made in the 1880 's. However, unlike photographs made on expeditions abroad, Potteau's photographs of official dignitaries and visitors to the Jardin des Plantes in Paris ${ }^{5}$ were made in his studio in the proximity of the Muséum d'Histoire naturelle and exhibit the aesthetics of traditional portraiture.

\footnotetext{
3580 of Potteau's 1138 negatives made for the museum were "photographs of the human races," as quoted in Christine Barthe, "Models \& Norms: the relationship between ethnographic photographs and sculptures," in Facing the Other: Charles Cordier (1827-1905) Ethnographic Sculptor (New York: Harry N Abrams, 2004$), 108$. This number does not include negatives by Rousseau that were included in the series.

4 The label number is also the subject number. Each subject photographed was assigned a number; therefore, if there are two views of the subject, they have an identical label.

5 The Jardin des Plantes is a botanical garden, which is part of the Muséum d'Histoire naturelle.
} 
Fig. $1 \& 2$

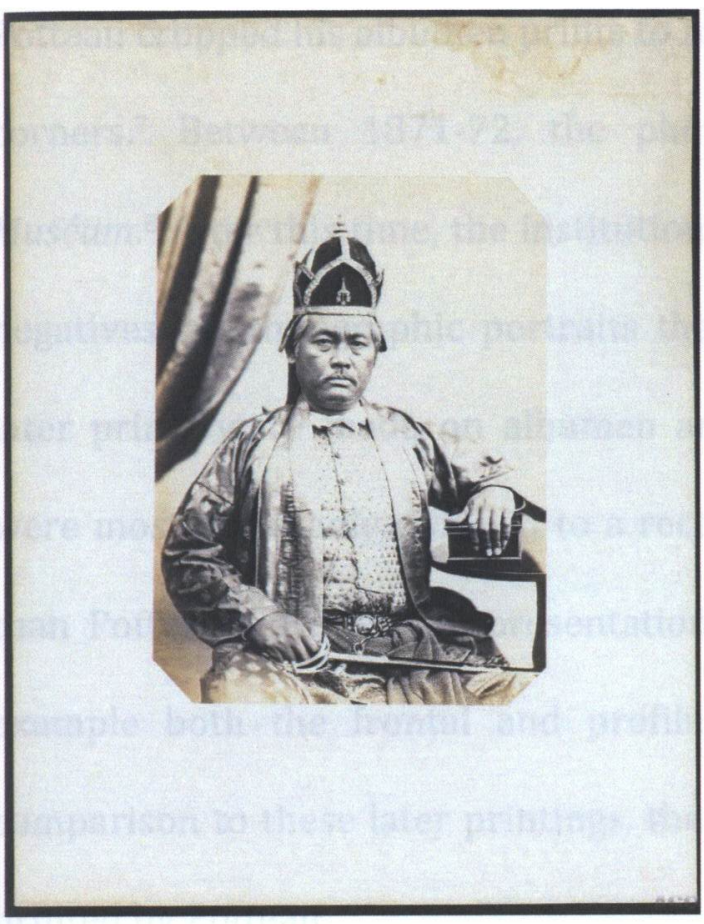

Jacques-Philippe Potteau

63. Hluang Indimontry (46 ans) Officier en chef pour le recouvremens des impôts provenans des différentes monopoles de la ville de Bangkok, au service de S. M. le 1er roi de Siam; chargé des cadeaux royaux envoyés a SM. I'Empereur des Francais. Né á Bangkok (Siam) d'un pere Chinois en d'une mere Siamoise. [Hluang Indimontry (46 years old) Officer in chief for the collection of provincial taxes of the various monopolies of the city of Bangkok, in the service of $\mathrm{H}$. M. the 1. King of Siam; in charge of royal gifts sent to H.M the French Emperor. Born in Bangkok (Siam) to a Chinese father and Siamese mother.] 1862

$15.3 \mathrm{~cm} \times 20.3 \mathrm{~cm}$

Albumen Print from Wet Collodion Negative Art Gallery of Ontario, Toronto

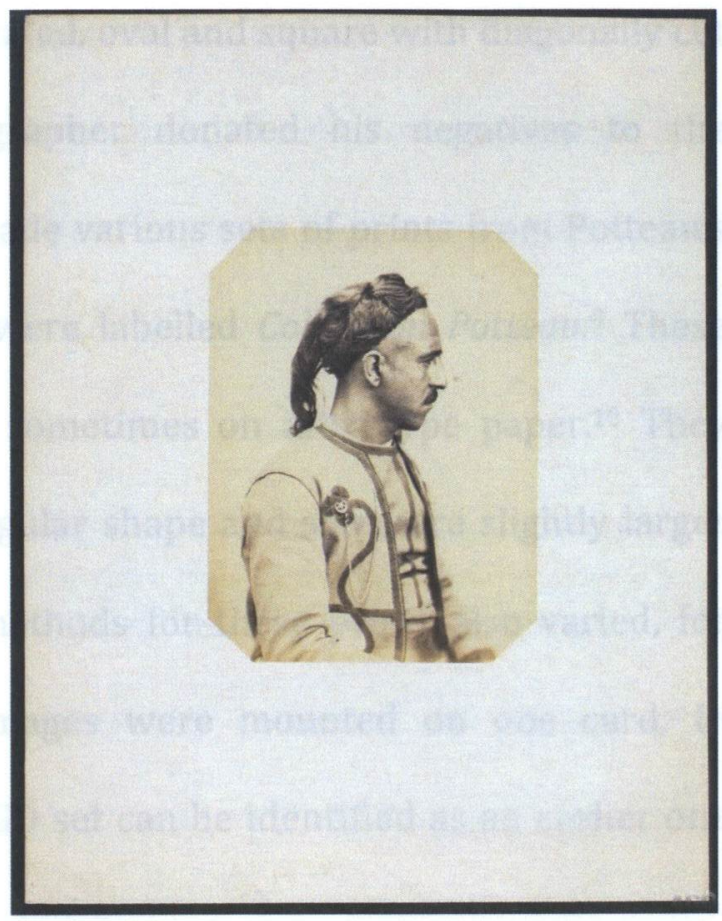

Jacques-Philippe Potteau

253. Moustapha Ben Onarga (26 ans) Soldat de 1er classe au 2e Tirailleurs Algériens, né à Tlemcen. Taille: 1m. 68cent. - Cheveux noirs, yeux bruns (Son père et sa mère Turcs) [Moustapha Ben Onarga (26 years old) Soldier of the 1 class in the 2 Algerian Tirailleurs, born in Tlemcen. Height: $1 \mathrm{~m}, 68 \mathrm{~cm}$ - Black hair, brown eyes. (His father and mother Turks)] 1865

$12.6 \mathrm{~cm} \times 16.6 \mathrm{~cm}$

Albumen Print from Wet Collodion Negative Art Gallery of Ontario, Toronto

Many sets of images were printed from the negatives in the series. The sets produced before 1871 were most likely printed by Potteau and bear the Collection 
Anthropologique title on a printed or handwritten label on the verso of the mount. 6 Potteau cropped his albumen prints to rounded, oval and square with diagonally cut corners. $^{7}$ Between 1871-72, the photographer donated his negatives to the Muséum. ${ }^{8}$ After this time, the institution made various sets of prints from Potteau's negatives of ethnographic portraits that were labelled Collection Potteau. ${ }^{9}$ These later prints were made on albumen and sometimes on aristotype paper. ${ }^{10}$ They were most commonly cropped to a rectangular shape and some are slightly larger than Potteau's prints. The presentation methods for these prints also varied, for example both the frontal and profile images were mounted on one card. In comparison to these later printings, the AGO set can be identified as an earlier one printed by Potteau.

What began as my assessment of the AGO set, focusing on the identification of individual images and their organization, developed into an investigation concerning the circumstances of their production and Potteau's involvement in it. The composition and presentation of Potteau's portraits vary; on the one hand, there are photographs of Siamese delegates made in the tradition of studio portraiture with curtains, decorations and props in the image and, on the other, clinical views of Algerian military men, removed from any context, staring blankly at

\footnotetext{
${ }^{6}$ I have seen or know of at least five sets of Collection Anthropologique probably printed by Potteau, including the AGO set. It is possible that Potteau had assistance in printing his images, which was common in photographic practice at the time.

${ }^{7}$ Christine Barthe, curator at the Musée du quai Branly, in personal communication with the author, June $16^{\text {th, }}$ 2009.

8 Barthe, "Models \& Norms," 108.

9 The Collection Potteau inventory was a catalogue of Potteau's negatives of ethnographic portraits compiled by the Muséum after the donation. Throughout their history, many prints in Parisian institutional collections were relabelled. For instance, the labels handwritten in pencil on the verso of Potteau prints were sometimes erased and replaced with labels handwritten in ink, identifying them as Collection Potteau.

10 The aristotype is a printing-out process using paper coated with silver chloride in gelatin or collodion.
} 
the camera or in profile. Furthermore, each label includes varying amounts of quantifiable (hair and eye colour) and subjective ("very pure race") information, depending on the subject and what the photographer considered important. ${ }^{11}$ This variance presents a number of questions about Potteau's approach to the subject and his mode of production, implicating him in a different role than has previously been understood.

It has been suggested that the photographer worked within the Muséum ${ }^{12}$ and produced photographs specifically for its collection. However, in the mid nineteenth century, only a few decades after the invention of photography, museums did not employ photographers as dedicated staff. As Potteau's history of employment within the Muséum reveals, he worked in different departments, under various titles, none of which were "photographer." His skill as a photographer was applied in a studio located near the institution. The Collection Anthropologique series is the largest body of work in Potteau's career. How does it define his mode and scope of production and what does it reveal about his employment within the Muséum? His approach mirrored the model of commercial photographic production at the time and the series was targeted for use by the scientific community, newly founded societies of learned men with interests in ethnography, anthropology and geography. The existence of various sets, such as the one at the AG0, attests to their dissemination and broadens our understanding of Potteau's production, showing that he did much more than merely contribute photographs to the Muséum's

\footnotetext{
${ }^{11}$ It is also possible that the photographer was instructed as to what the type of information he was to record. 12 Barthe, "Models \& Norms," 106-108; P-J. Jehel, "Photographie et anthropologie en France au XIXe siècle" (Mémoire de DEA, Université Paris VIII, 1995), 35.
} 
Anthropology Collection. ${ }^{13}$ This thesis analyzes the set of photographs in the AGO collection as well as the labels accompanying the set, which have not previously been considered as a source of information about the photographer. It demonstrates that Potteau's production was more independent of the institution than has hitherto been understood.

\footnotetext{
13 The Anthropology Collection at the Muséum d'Histoire naturelle included all objects in the custody of the Anthropology Laboratory, not to be confused with the Collection Anthropologique photographic series, which was only a part of this collection.
} 
There is a lack of published information specifically about the 'Collection Anthropologique' series. However, that which does exist is helpful in placing the AGO set of photographs into a context. The history of this set begins with the cultural context of its creation, discussed at length in Elizabeth Anne McCauley's Industrial Madness: Commercial Photography in Paris, 1848-1871. Her comprehensive account of the growth of commercial photography at this time is valuable in constructing a framework for understanding the creation and consumption of these images. The establishment of commercial portraiture in Second Empire France had an undeniable influence on Potteau's approach to making anthropological photographs, the protocol for which had not yet been fully determined, as one can see by observing the gap between the two examples presented above (Fig. $1 \& 2$ ).

McCauley includes both Rousseau and Potteau in her history of commercial photographic production in Paris, placing them among other makers of commercial products ${ }^{14}$ specifically targeted for consumption by the scientific and academic communities. She refers to Rousseau as a "naturalist" who made a reputation photographing exotic "human and animal specimens,"15 in reference to the photographs of 'Eskimos' that he took during Prince Jérôme Napoleon Bonaparte's 1856 expedition to Iceland and Greenland. ${ }^{16}$ These are some of the first images to be represented in the Collection Anthropologique series. She accounts for Potteau

\footnotetext{
14 Rousseau's work is included among 3.6\% of prints of 'scientific studies' registered in the dépôt légal listings in 1853. By 1868, the 'scientific studies' category seems to be absorbed into miscellaneous images and the percentage of registrations declines to 1.4\%. Elizabeth Anne McCauley, Industrial Madness: commercial photography in Paris, 1848-1871 (New Haven, Connecticut: Yale University Press, 1994), 97.

15 McCauley, Industrial Madness, 307.

16 McCauley, Industrial Madness, 97.
} 
having exhibited "three albums of human racial types"17 taken for the Muséum d'Histoire naturelle at the ninth exhibition of the Royal Photographic Society (RPS), in $1863 .{ }^{18 \& 19}$ It is very likely that these images were the same ethnographic portraits that were part of the Collection Anthropologique series; however, there is little evidence of the albums themselves. Potteau is often overshadowed by Louis Rousseau, whose contribution to the series was significantly smaller, but who was a much more prominent figure in photographic circles.

Using the camera as a tool for observation, scientific communities, societies of learned men and institutions such as the Muséum d'Histoire naturelle attempted to record 'invisible phenomena'20 to present and support their ideas about the world. Marta Braun examines the value and validity of photographic observations made in the name of science in her article "La photographie et les sciences de l'observation" [Photography and the science of observation.] Early applications of photography to exploring micro and macrocosms were unsuccessful because it was unable to accurately represent colour, three-dimensional form, scale, distance or motion. In anthropology, unlike the case of astronomy, botany, medicine or kinetics,

\footnotetext{
17 McCauley, Industrial Madness 383, note 144.

18 McCauley, Industrial Madness 93, Potteau was awarded an honourable mention for his work, which was displayed in the main hall of the London exhibition.

19 According to the "Photographic Exhibitions in Britain 1839 -1865" web-catalogue compiled by Roger Taylor, apart from these three albums, Potteau also exhibited three prints titled "Application of Photography to Anatomy and Natural Sciences, Types of Different Sections of the Human Race, and Objects of Natural History" for which he was also awarded an honorable mention, as well as two other similar photographs, twelve photographs titled "Types of the Human Race" and one photograph from a waxed-paper negative titled [Coral]. Taylor's catalogue does not mention any association to the Muséum, however, it names the Société française de photographie as the exhibitor of Potteau's photographs.

http://peib.dmu.ac.uk/itemphotographer.php?photogNo=1194\&orderby=coverage \&photogName=Potteau $\% 2 \mathrm{C}$ + Phillipe+Jacques+\%281807-1876\%29, (accessed, September 5th 2009 ).

20 Marta Braun, “Aux Limites du Savoir: la photographie et les science de l'observation" in L'Art de la photographie des origines à nos jours, ed. André Gunthert and Michel Poivert (Paris: éditions Citadelles-Mazenod, 2007), 174
} 
photographic observations continued to weigh heavily on 'faith' for their validity. ${ }^{21}$ Theories of racial hierarchy thrived on this same faith in observation as science struggled to produce evidence to support them.

In her book Raw Histories, Elizabeth Edwards ${ }^{22}$ investigates the materiality of anthropological photographs and how they managed to convey such an authoritative message. ${ }^{23}$ The indexical value of a photograph attests to its power; as Edwards puts it, "It was there." 24 The photographs, in everything that cannot be known about them, are as uncertain as the culture that created them: a culture not fully resolved in its conceptual framework of looking at the 'other.' Edwards demonstrates how the 'rawness' of colonial photographs, on par with the rawness of the culture that created them, allows them to be viewed today in a post-colonial context. Her discussion helps to consider the trajectory of the numerous sets of the Collection Anthropologique series, their dissemination and consumption. ${ }^{25}$

In her article, "Models \& Norms: the Relationship Between Ethnographic Photographs and Sculptures," published in Facing the Other: Charles Cordier Ethnographic Sculptor, Christine Barthe ${ }^{26}$ looks at the terms of production of photographs and sculpture in the mid-nineteenth century and their "museological fate." 27 The discussion is built around the duality of these objects as both scientific

\footnotetext{
${ }^{21}$ Braun, "Aux Limites du Savoir," 175.

22 Edwards is curator at the Pitt Rivers Museum in Oxford and the foremost scholarly source on anthropology and photography.

23 Elizabeth Edwards, Raw Histories: Photographs, Anthropology and Museums (Oxford: Berg, 2006).

24 Elizabeth Edwards, ed. Anthropology and Photography 1860-1920 (New Haven, CT: Yale University Press, 1992), 7.

25 The AGO set is an interesting example because it is the only one I have come across that is part of an art gallery collection.

${ }^{26}$ Barthe is curator of photographs at the Musée du quai Branly in Paris and was previously head of the photography collection at the Musée de l'Homme.

27 Barthe, "Models \& Norms," 93.
} 
specimens and art. Barthe investigates the growth of the Anthropology Collection at the Muséum d'Histoire naturelle through the acquisition and commissioning of various objects of study including sculptures, plaster casts and photographs.

Barthe's account of Potteau's work for the Muséum and his contribution of photographs to the Anthropology Collection provides insight as to the circumstances and extent of the photographer's production. However, her sources do not clarify his terms of employment with the institution and are in some respects contradictory. Barthe quotes from writings by Armand de Quatrefage (1867), head of the Human Anatomy and Natural History laboratory, where he addresses the photographs of "M. Potteau, employed by the Museum ... [as] true scholarly works." ${ }^{28}$ Further, she quotes the foreword to Quatrefage's Histoire générale des races humaines (1871), where he mentions Potteau as a "simple employee of the Museum."29 But, if Potteau's terms of employment with the museum were so simple, why did Quatrefage have to purchase photographs from Potteau in $1863 ?^{30}$ In 1867, Quatrefage once again requested funds to purchase Potteau's photographs of Bohemians. $^{31}$ Finally, in 1871-72, Potteau gifted 1138 negative plates to the museum, ${ }^{32}$ further calling into question the terms of his employment and production. Presumably, had Potteau's employment within the institution included his photographic practice, the plates would have belonged to the museum as with any other specimens prepared by an employee in the laboratory.

\footnotetext{
${ }^{28}$ As quoted in Barthe, "Models \& Norms," 106.

29 Ibid.

30 Barthe states that "18 prints of Parsis types" were purchased by Quatrefage, ibid.

31 Ibid.

32 Ibid.
} 
Pierre-Jérôme Jehel's thesis "Photographie et anthropologie en France au XIXe siècle" [Photography and Anthropology in nineteenth-century France], looks at the historical and political development of anthropology in the early nineteenth century to later applications of photography in creating anthropological collections. He sees these bodies of work as representative of the culture that created them, rather than the cultures they depict, and questions the representation of the 'other'33 and the blurred lines between art and the scientific method. Jehel devotes a section to analyzing the work of Potteau and compares his approach to commercial photographic production at the time. He focuses specifically on the group of portraits of the members of the Siamese Embassy, ${ }^{34}$ photographed in 1861-62, which he compares to portraits of the same group made by Nadar. ${ }^{35}$ He draws direct parallels between the established protocols used in studio portraiture and those adopted by Potteau in photographing the subject for the purpose of scientific observation. Jehel concludes, and I agree, that Potteau was tactful in photographing his subjects, giving due respect to his sitters, in contrast to Rousseau, whose portraits of 'Eskimos', are not only of lesser quality, ${ }^{36}$ but objectify the subject in a much more obvious way. ${ }^{37}$ Jehel also states that there is little, if any, biographical information available about Potteau. ${ }^{38}$ Further, he provides a number of nineteenth century sources to confirm Boucourt and Rossier's contribution to the series.

\footnotetext{
33 Jehel, 6.

${ }^{34}$ As seen in Figure 1.

35 Jehel, 40-41.

36 In La Revue Photographique, January 5, 1857, Louis Figuier acknowledged the poor weather conditions and volatility of collodion as obstacles in producing plates of better quality, Jehel, 30.

37 Jehel, 35.

38 Jehel, 126.
} 
Although dealing with the same material as this investigation, a set of photographs by Potteau from the Collection Anthropologique series, found at the Bibliothèque nationale de France $(\mathrm{BnF})$ and the Musée de l'Homme, ${ }^{39}$ Jehel's $^{\prime}$ analysis is focused on a specific selection of images and does not address the labels as a source of information about them or the photographers.

In approaching the problem of how to look at and interpret anthropological photographs, I consulted Anthropology \& Photography, edited by Elizabeth Edwards. Her compilation of essays examines a variety of anthropological photographs, their political and historical context, and the concept of looking at the 'other.' It offers a theoretical framework for approaching this type of material. In her introduction, Edwards states that there is no truth to historical photographs nor is there a "key to a cultural decoding" 40 of their creation. She encourages her audience to 'read' these photographs as they have many interpretations and meanings.

Joanna Scherer's essay "The Photographic Document: Photographs as Primary Data in Anthropological Enquiry" in Anthropology \& Photography offers a useful methodology for examining anthropological photographs as documents, which was partially applied to this investigation. Her method prescribes analysing the original images and comparing them to others; contextualizing the material in the history of photography and accounting for the limitations of the medium and context; investigating the photographers' intent and assumed use; employing the

\footnotetext{
39 This collection is now at the Musée du quai Branly.

40 Edwards, Anthropology \& Photography 5.
} 
"study of ethnographic subjects" through cultural studies; and reviewing the "historical evidence," taking into account the treatment of the material by others. ${ }^{41}$ Elizabeth Edwards ed., Anthropology \& Photography 1860-1920 (New Haven, CT: Yale University Press, 1992), 33. 
1 | Anthropology \& the photographic industry

Photography and anthropology, both in their infancy in the mid nineteenth-century, shared a reciprocal relationship as they developed. Anthropology, based on the biological sciences, helped to assert Western knowledge, and consequently the white race, as superior. ${ }^{42}$ Through observation, documentation and classification, anthropology sought to reveal 'scientific truth' about humankind. Photography appeared to be the ideal tool for producing tangible evidence to support anthropology's far-reaching theories, which claimed the dominance of some ethnicities over others. With the creation of series such as the Collection Anthropologique, anthropology classified human beings according to race and established Europeans as the superior race at the top of the pile. ${ }^{43}$ The "Western perception" 44 of other cultures was dependent on both the "creation and consumption" of ethnographic photographs and led to the dissemination of Darwin's theories, which in turn drew from these type of fabrications. ${ }^{45}$

In Second Empire France, the second decade of photography saw a boom in its commercial exploitation and applications. This flourishing of the photographic industry was due to a growing culture of consumption, but also the wide-spread use of the wet-collodion process, which bore reproducible fruit. The process was

\footnotetext{
42 Edwards, Anthropology \& Photography, 5; Braun, “Aux Limites du Savoir," 176.

43 Potteau's negatives were re-catalogued geographically by the Muséum d'Histoire naturelle in the 1870's; the list began with Europe, France.

44 Edwards, Anthropology \& Photography, 5.

45 Braun "Aux Limites du Savoir," 176; Charles Darwin, "Chapter VII: On the Races of Man" in Descent of Man and Selection Relating to Sex (New York, NY: AMS Press, 1972). Darwin consulted this series of 'scientific specimens' to build his arguments.
} 
cumbersome and its limitations were numerous, but photography was finally able to duplicate the world indefinitely, with great clarity and precision. The inexpensive and accessible wet-plate turned everything observable by industrious eyes into tangible, marketable objects. ${ }^{46}$ This marvel of vanity and curiosity led to the increased desire of Western scholars, who supported theories of racial hierarchy, to objectify others. The roots of this desire were long ago in place, exercised in conquest and colonization; but the camera became yet another tool of power employed by Europeans.

The overwhelming number of studios and photographic ventures in Paris eventually distilled into more specialized categories of industrial and scientific photography, among which anthropological photographs found a viable market. ${ }^{47}$ These types of images were widely disseminated, exhibited in museums and industrial fairs and traded among learned men.

There was no concrete formula for making anthropological photographs. Some basic protocols were employed including views from different perspectives and descriptive labels; however, overall, ethnographic portraits mimicked the established traditions of portraiture. Unlike later anthropological photographs, where the subject is posed (often nude) against an anthropometric scale, or those produced as supplements to field work, the ethnographic portraits from the Collection Anthropologique series exhibit the aesthetics of traditional studio portraiture of such notable contemporaries as Nadar ${ }^{48}$ and Disderi.

\footnotetext{
${ }^{46}$ Compared to the daguerreotype, the wet-plate collodion process was cheaper and therefore more accessible, contributing to the rapid growth of commercial photography in the mid-nineteenth century. 47 McCauley, "The Business of Photography," in Industrial Madness, 49-56.

${ }^{48} \mathrm{Jehel}, 40$. The author compares Potteau's images to those of the same subjects taken by Nadar.
} 
Étienne Serres, director of the Human Anatomy and Natural History laboratory at the Muséum d'Histoire naturelle from 1839 until 1855, ${ }^{49}$ recognized the potential application of the camera immediately. In 1841, Serres purchased an appareil de Daguerre for 260 francs. ${ }^{50}$ Louis Rousseau (1811-1874), employed by the Muséum as a laboratory technician and assistant in the zoology department, soon learned to operate the apparatus, which was seen not only as a viable way to preserve the collections, but was also used to produce some of the first images of humans at the Muséum. ${ }^{51}$

\section{2 | The Photographers}

Rousseau was introduced to photography within the institution and took lessons from Niépce de Saint Victor and Hippolyte Bayard. ${ }^{52}$ In 1854, he became one of the founding members of the Société Française de Photographie and was official photographer of the Muséum d'Histoire naturelle until $1860 .^{53} \mathrm{He}$ also partook in several important expeditions, including Prince Bonaparte's 1856 expedition to Iceland and Greenland, where he made photographs of natives, some of which are included in the Collection Anthropologique series. Rousseau gave up photography in $1862 ;^{54}$ however, his relationship to the Muséum continued. In 1872, he was made custodian of the Zoology department. ${ }^{55}$

\footnotetext{
${ }^{49}$ Barthe, "Models \& Norms," 94.

50 Jehel, 31; Barthe, "Models \& Norms," 94.

51 Jehel, 30-31.

52 Jehel, 32.

53 Ibid; McCauley, Industrial Madness.

54 Jehel, 35.

55 Jehel, 28.
} 
Rousseau probably introduced Potteau to photography as both were employed by the institution and making photographs on the cusp of the 1860 's. ${ }^{56}$ The latter dedicated the next decade of his career to creating over 1000 photographic plates for the Muséum, many of which are those represented in the Collection Anthropologique series. Although little is know about him, Potteau's (1807-1876) presence can be traced within the Muséum d'Histoire naturelle over nearly 30 years. The first account of his activity in the institution is in 1838, and records from the 1850 's indicate his employment as assistant in the geology and mineralogy laboratories. ${ }^{57}$ He began to build on Rousseau's photographic work for the institution after $1860,{ }^{58}$ creating ethnographic portraits as well as photographs of various museum specimens, and reproductions of art. The Collection Anthropologique series offers insight into Potteau's mode and scope of production.

The terms of his employment by the Muséum d'Histoire naturelle are unclear. Several sources indicate that he was employed by the Muséum throughout the 1860 's. However, Potteau also sold his prints and donated his negative plates to the institution, ${ }^{59}$ indicating that his means of production was independent. The sheets of labels investigated in this paper suggest that Potteau produced images for various institutions around Paris. He is also known to have presented his work to Société Française de Photographie in $1862^{60}$ and $1863^{61}$ and exhibited work in England. ${ }^{62}$

\footnotetext{
56 Jehel, 35.

57 Barthe, "Models \& Norms," 106.

58 According to Jehel, Potteau began making photographs for the museum in 1861, however, my research points to earlier work. It is also possible that he made photographs prior to 1860 , as there are 'unsigned' labels from 1857 and 1859, which according to the hypothesis presented in this paper implicate him as the maker.

59 Barthe, "Models \& Norms," 108.

60 Jehel, 36.

61 Barthe, “Models \& Norms," 106.
} 
The views made by Swiss born photographer Pierre-Joseph Rossier (18291898) included in the AGO set of images were not credited directly to him, but rather French naturalist and artist Firmin Bocourt, who contributed these to the series. By 1861, Rossier, who had been working in Japan for the London photographic firm of Negretti and Zambra producing commercial travel images, ${ }^{63}$ ended up in Siam where he assisted Bocourt in taking ethnographic portraits that were later assimilated into the Collection Anthropologique series. He eventually returned to Switzerland where he owned and operated independent portrait studios in Einsiedeln and Fribourg. ${ }^{64}$ There is no further evidence implicating his association to the series or the Muséum.

62 McCauley, Industrial Madness, 93; Taylor, "Photographic Exhibitions in Britain 1839-1865," http://peib.dmu.ac.uk/, (accessed September 5th, 2009).

63 Bennet, Terry, Bourgarel, Gérard and David Collin, Pierre Joseph Rossier, Photographe: une mémoire retrouvée, (Fribourg, Switzerland: Pro Fribourg, 2006).

64 Bennet et al., 25. 
In following Scherer's methodology, I consulted the image set at the AGO as the point of entry to the investigation of the series. By looking at the labels on the photographs in the AGO set, I was able to analyze the organization and the scope of the series and identify Potteau as instrumental in its creation. Insofar as the AGO set offered limited information as to the circumstances of the production of the series, it was necessary to establish the historical context and further consider the limitations of the medium in producing a scientific specimen.

In order to see how the AGO set was representative of the series, I decided that it would be helpful to survey another comprehensive set of the Collection Anthropologique. Sets can be found at the Pitt Rivers Museum in Oxford, ${ }^{65}$ the Tozzer Library at Harvard, the BnF and the Musée du quai Branly (quai Branly) in Paris. Many of the original negatives from the series and some collection documentation are also at the quai Branly. ${ }^{66}$ The fact that various sets exist attests to the claim that these images were produced on a large scale, more than necessary to meet the demand of the Anthropology Collection at the Muséum d'Histoire naturelle.

I was able to spend a week in Paris and survey sets of the Collection Anthropologique series in the holdings at the BnF. The library's catalogue listed Collection Anthropologique images only under Potteau's name. The BnF has a total of

\footnotetext{
65 Information about the Collection Anthropologique images can be accessed through the museum's online database. 66 There is no original inventory of the Collection Anthropologique negatives; it is therefore unknown exactly how many negatives the series consisted of.
} 
338 images by Potteau, ${ }^{67}$ which they acquired from two separate donations. The first donation, in 1955, was from "French industrialist Georges Sirot,"68 and identified with a "Sir" blind stamp on the image. These prints are labelled Collection Anthropologique and can be identified as a set printed by Potteau. The second donation was from the Musée de l'Homme ${ }^{69}$ and contains both prints by Potteau and later prints labelled Collection Potteau; therefore, these are two separate sets. Because there are three sets of prints, there are a number of duplicate images. These duplicates are from different printings; they have different presentations and vary in format. The library's online catalogue provides a brief record of each image, listing information from 330 of the Collection Anthropologique image labels, sorted geographically. The eight remaining images by Potteau do not have a record in the online catalogue.

Among the few Potteau images at the BnF that did not belong to the Collection Anthropologique series were eight photographs of reliefs, which appear to be architectural ornaments of a religious nature. The albumen prints, presented in a very similar manner to those in the Collection Anthropologique, bear two significant markings. The first is a small red stamp in the image that reads "Bibliothèque Impériale," indicating that these images were produced between 1848 and 1871, when the French National Library was known as the Imperial Library. The second marking is a blind stamp, centred in the lower portion of the image mount; it reads

\footnotetext{
${ }^{67}$ Bibliothèque nationale de France, BnF catalogue general, http://catalogue.bnf.fr/servlet/NoticeAutorite?host=catalogue, (accessed July 7, 2009).

68 Andréa R. Vaucher “A New Focus” France Magazine 66, (Summer 2003), http://www.francemagazine.org/articles/issue66/article68.asp?issue_id=66\&article_id=68, (accessed July 7, 2009).

69 According to a BnF librarian, the Musée de l'Homme made several donations to the library at different times.
} 
"Potteau | Rue Guy de la Brosse," an address in the proximity of both the Jardin des Plantes and the Muséum d'Histoire naturelle. These markings affirm that Potteau was in fact producing images independently of the Muséum and that he operated a studio. ${ }^{70}$

At the Musée du quai Branly, I had a brief look at the Potteau and Rousseau holdings, as well as a general overview of the museum's collection of anthropological photographs. The quai Branly inherited a large portion of its holdings from the Musée de l'Homme, which in turn inherited much of the Muséum d'Histoire naturelle Anthropology Collection. I discussed my research with the curator of photographs, Christine Barthe, who has in-depth knowledge of the collection having worked at the Musée de l'Homme for many years. I was able to learn about the fate of the objects that had been passed down from institution to institution and the many incarnations they experienced..$^{71}$ Many of the prints, both early ones printed by Potteau and later ones printed at the institution, had been removed from their original mount cards and re-mounted or the cards had been cut down in size, eliminating original labels. All of the information gathered helped to identify the AGO set as an early one printed by Potteau.

I was also able to see a set of the Collection Anthropologique at the Tozzer Library at Harvard University, which is the most comprehensive set printed by

\footnotetext{
70 I have found no further evidence of Potteau operating a studio, however, a blind stamp with an address is very suggestive of one as most commercial photographers at this time identified their work in this way.

71 The quai Branly's online 'Catalogue de l'iconothèque' lists 1620 photographic objects attributed to Potteau, which include 545 glass plate negatives, 620 albumen prints and 410 aristotypes (printing-out-paper process), and 45 views in other formats. Some of the print objects are composed of more than one print mounted onto a single card. Potteau is credited in any of the following three fields: photographer and/or previous collector and/or creator of the duplicate negative, i.e. the list includes images taken by others from which Potteau made duplicates, both negative and print. Although most of the negatives and prints listed are ethnographic portraits, there are several images of skulls.
} 
Potteau of all those surveyed. It contains 775 images in six bound volumes and was acquired (probably in the late 1860's - early 1870's) for the Library of the Museum of Comparative Zoology at Harvard College, founded by Louis Agassiz ${ }^{72}$ in 1861. In 1910, the albums were donated to the Peabody Museum Library (now the Tozzer Library) by Agassiz' son Alexander. The set was bound after acquisition; each volume is accompanied by a hand written list of all the images contained in the album and arranged according to a geographic system devised by the collector. The original organization of the series is sequential according to the numbers on the labels; each label has a number and refers to a specific subject. Multiple views of the same subject have the same label.

Volume number $\mathrm{V}$ is an exception to the lot. ${ }^{73}$ It is an album of frontal and profile views of plaster casts of human heads. This volume contains 262 images and introduces the greater scope of the Collection Anthropologique series. The images bear a label titled "Collection Anthropologique du Muséum de Paris," with one distinction below the title, which does not appear on the portrait labels: "Bustes moulés sur nature - par M. Dumouthier, Expedition d'Urvile de 1837 à 1840." The images are likely also by Potteau as he is known to have photographed busts from the Dumouthier Collection. ${ }^{74}$

I used the AGO set of images as a base of comparison for looking at all the sets discussed above. Prior to seeking out sets in other collections, I constructed a

\footnotetext{
72 Louis Agassiz was a distinguished Swiss scientist who was likely the person responsible for the initial acquisition of the set now found at the Tozzer Library. It is also possible that his son Alexander Agassiz, also a scientists, who is known to have communicated with Armand de Quatrefage, was responsible for the acquisition. 73 The volume numbers were assigned by the Tozzer Library in order to identify the individual albums, which are accessioned as a single lot.

74 Potteau's donation of plates to the Muséum included 102 plates from the Dumouthier Collection and another 90 plates of busts according to Barthe, "Models \& Norms," 108. However, this presents a discrepancy with the number of views in the album, as 70 plates are unaccounted for.
} 
database to organize the information garnered from the AGO set, which had not been catalogued in the museum's database. The original acquisition was accompanied by a basic Excel spreadsheet from the donor, which provided imprecise and sometimes erroneous data about the photographers and label information. I built the database in accordance with the standards for object documentation outlined in the Getty Research Institute's Categories for the Description of Works of $\mathrm{Art}^{75}$ with two objectives in mind: to accurately identify the correct maker of each image and to record complete label information. The process of gathering this information allowed me to become familiar with the range of images and further to interrogate the set for statistics, about the presentation, image content and label information, for example: What is the most common type of presentation? How many images contain props? Or, with what consistency is the subject's age recorded on the label? (see Appendix II)

The labels were approached separately from the images because of the wealth of information that they provide about the photographer, the organization of the series and the process of producing a specimen marketable to the scientific community. They can be seen as the unifying factor that defines the intention of the series and in turn Potteau's approach. The investigation of the labels looked separately at the object-specific examples and the sheets of uncut labels, one contributing to the creation of a specimen and the other to the systematic classification of types.

\footnotetext{
75 The Getty: Research Institute Home: Conducting Research: Data Standards and Guidelines: Categories for the Description of Works of Art http://www.getty.edu/research/conducting_research/standards/cdwa/, (accessed July $\left.31^{\text {st }}, 2009\right)$.
} 
Potteau produced not only ethnographic portraits, but also photographic reproductions of artworks, such as those in the $\mathrm{BnF}$ collection that bear his studio stamp, and images of various specimens for institutional collections, as evidenced by the labels (discussed in detail under Labels: Uncut Sheets). He can be considered, at least in some part, an independent operator. His work was specific to the scientific community and its institutions and produced on different terms than the work of his contemporaries in the same industry. This investigation was not sufficient to determine the how much photographic work he produced; however, we are able to discuss the Collection Anthropologique series as a starting point for looking at his output.

The AGO set of images is limited because it is not a complete set; however, it does provide several leads about the series and Potteau's photographic production. When I first began investigating the set of images at the AGO, what exactly the Collection Anthropologique series consisted of was unclear. However, it was apparent that the series was larger than what the AGO had. I began by trying to determine the scope of the series by looking at the AGO set. ${ }^{76}$ The set was offered as a donation to the AGO in 2006. The donor, the Archive of Modern Conflict, based in London, UK, acquired it through auction. ${ }^{77}$ The original lot, offered by Bloomsbury Auctions, Sale \#488 on 21 May, 2004 in London, included 280 objects and listed

\footnotetext{
${ }^{76}$ My research focused on the ethnographic portraits included in the series and I cannot say how many other photographs were included in the series. Reconstructing the series would be a considerable task as there is no original documentation pertaining to the series.

77 Confirmed by Barbara Adams, Archive of Modern Conflict, e-mail communication with the author, July $15^{\text {th }}$, 2009.
} 
both Rousseau and Potteau as the photographers responsible for the images. ${ }^{78}$ The set of 10 sheets of uncut printed labels was also part of the lot. The donor kept 27 photographs from this lot as a "representative sample." 79 The donation was presented to the AGO acquisition committee as containing images by Rousseau; 80 henceforth, the AGO staff had assumed that the set included images by him. Since being acquired in 2007, the set had not been catalogued in the museum's database and no research had been done on the images. Through this investigation, I have confirmed that there are no images by Rousseau in this set.

There is no evidence of an original inventory listing all of the negative plates included in the series. ${ }^{81}$ The image labels were numbered consecutively with each number corresponding to one subject; multiple views of the same subject had the same label. According to the labels on the verso of the prints and on the sheets of uncut labels included with the AGO donation, aside from Potteau's portraits, ethnographic portraits taken by Louis Rousseau, Pierre Joseph Rossier under the direction of Firmin Bocourt, Paul-Émile Miot, M. le Comte de Montblanc, M. L. d'Eichtal, and M. Henri de Lacaze-Duthiers and contributed by M. L'abbé Larnandie were included in the series. ${ }^{82}$ The number of works from each of these photographers and contributors is indeterminate. Eight of Rousseau's photographs

\footnotetext{
78 The original lot description indicates that the object label numbers ranged "between 13 and 299." Four of the images were listed as "signed" by Rousseau, which I believe is a reference to the credit on the label that appears as "Par M. Rousseau." Bloomsbury Auctions London, http://www.bloomsburyauctions.com/detail/488/39.0, (accessed November 11, 2008).

${ }^{79}$ Barbara Adams, e-mail communication with the author, July 15 th, 2009. This representative sample contains the four Rousseau images identified in the auction listing.

80 Research report for the Canadian Cultural Property Expert Review Board, prepared by Sophie Hackett, assistant curator of photography at the AGO.

81 The Collection Potteau inventory in the "Collection des Clichés" found at the quai Branly lists Potteau's negatives of ethnographic portraits and copy negatives made made by him from images by other photographers. 82 Among the other collections surveyed, the following contributors were also identified: M. du Chesne de Bellecourt (French Ambassador to Japan, 1866-67), M. le capitaine Aubaret (French Consul in Bangkok, 1865).
} 
from Prince Bonaparte's 1865 expedition (labels \# 5-12) were included in the original series; however, he is known to have brought back a total of 89 plates of various views. ${ }^{83}$ The reasoning behind certain images being included and not others is unclear. The same is true for images by other photographers and contributors; the number of views by each individual originally included in the series is unclear. According to the sheets of uncut labels, the series also included copy prints of daguerreotypes and drawings, such as the one of the infamous Hottentot 'Venus' (label \#4) and a photograph of her skull (label \#1603, discussed further under Labels). ${ }^{84}$

The uncut labels included in the donation are a "separate set of printed captions" as referred to in the Bloomsbury lot description. ${ }^{85}$ It is unclear why these accompanied a set of photographs that had labels attached. The labels on the sheets were printed in consecutive order beginning with the first sheet, label 1, i.e. subject 1, a 'Hottentot' from South Africa, photographed by Rousseau in 1855. There are two identical labels for this subject indicating that there should be two views two views of the subject. There is only one label for subject 2 , indicating that there is only one plate of this subject and so on. However, these labels do not provide consistent information about the number of negatives in the series. Among the AGO set of images, there are up to four views of one subject, specifically, number 145 Nguŷen bûn than, of the Cochin-Chinese Embassy in Paris, photographed in 1863

\footnotetext{
83 La Revue Photographique, January 5, 1857, as cited in Jehel, 29. The 89 plates included landscapes, views of Reykjavik, dwellings, ships, fishermen and portraits of men and women of different ages. 84 Unlike the portraits, where each subject is assigned one number and multiple views of that subject have the same label, the drawing and the skull, although they are from the same subject, are two separate objects and therefore have different label numbers.

85 Bloomsbury Auctions London, http://www.bloomsburyauctions.com/detail/488/39.0, (accessed November $11,2008)$.
} 
(Fig. 3). There are two three-quarter-length portraits, frontal and profile and two full-length portraits, one seated and one standing, in two different costumes. There is at least one other view of the same subject in the quai Branly collection, bringing the total to five views of one subject. ${ }^{86}$ There are only two labels for this subject printed on the uncut sheets, suggesting that the sheets of labels do not account for all the views.

Fig. 3

Jacques-Philippe Potteau

Ambassade Cochinchinoise à Paris. 145. Nguŷen bûn thân (30 ans) Né à Hue (Annam) Capitaine de la Garde Impérial. Mandarin de $5 \mathrm{e}$ degre, $2 \mathrm{e}$ classe. [Cochin-chinese Embassy in Paris. 145. Nguŷen bûu than (30 years old) Norn in Hue (Annam) Captain of the Imperial Gard Mandarin 5 degree, 2rd class], 1863.

$12.4 \mathrm{~cm} \times 18.2 \mathrm{~cm}$

Albumen Print from Wet Collodion Negative

Art Gallery of Ontario, Toronto

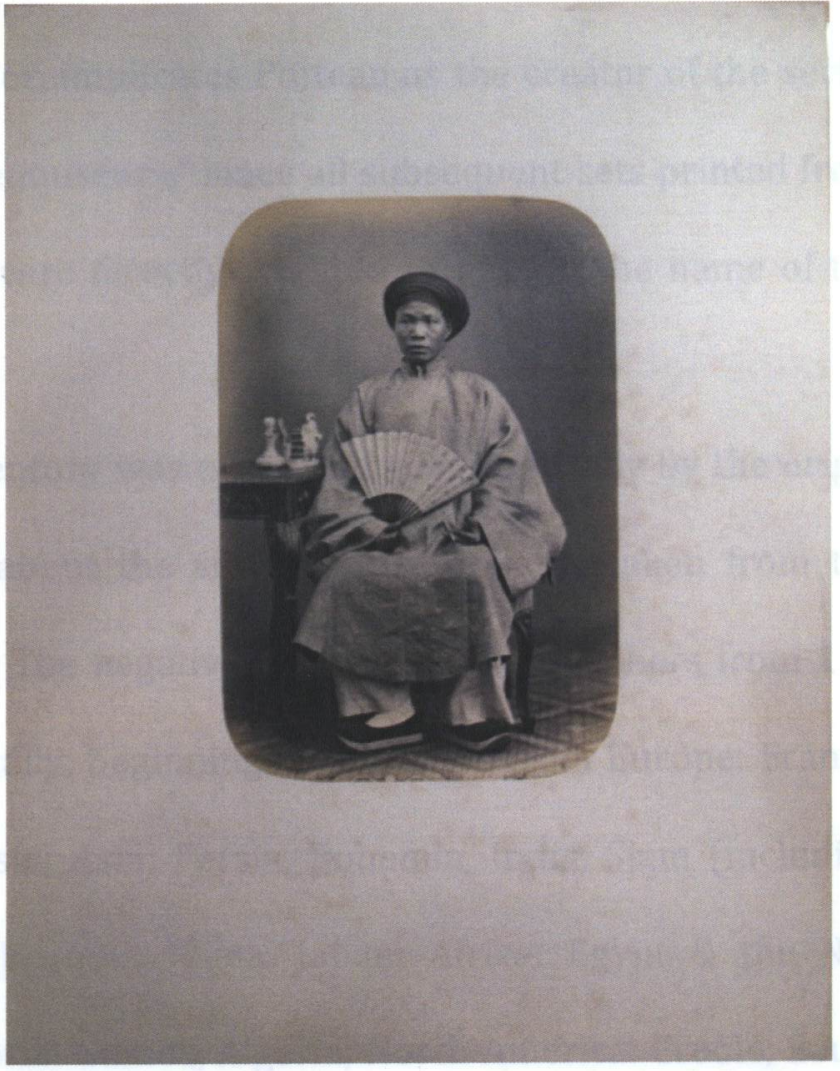

I was able to consult one other source found at the quai Branly in trying to determine the number of ethnographic portraits included in the series. The Collection Potteau inventory in the "Catalogue des Clichés photographiques, conservés

86 The Collection Potteau inventory lists five plates of this subject. 
au Laboratoire d'Anthropologie" lists $555^{87}$ negative plates of ethnographic portraits, donated to the museum by Potteau in $1871-72.88$ This catalogue, put together between 1879-1890, was the first re-organization of the plates of ethnographic portraits in the Collection Anthropologique series. It was divided into five inventories by photographer: 1, plates by Paul-Émile Miot; 2, “Collection des Clichés donnés par M. L. Rosseau"; 3, "Collection des Clichés donnés par M. d'Eichtal"; 4, "Collection Potteau"; and 5, plates by M. F. Deliste. ${ }^{89}$ The organizational principal of these inventories, the photographer, implicates Potteau as the creator of the series and not a "simple employee of the museum," since all subsequent sets printed from the Collection Potteau negatives were directly credited to him, in the name of the newly formed series.

The Collection Potteau inventory was organized geographically by the origin of the subject. The information about the subject was probably taken from the Collection Anthropologique labels. The negatives were assigned numbers from 1 to 555 and were divided geographically, beginning with entries from Europe: France, Italy, Denmark and Sweden, Russia; Asia: Persia, Bohemia, India, Siam (including Annam/Cochin-China, Myanmar/Burma,) China, Japan; Africa: Egypt \& the Nile Valley, Cap Vert (Senegal), Equatorial Guinea, Algeria; North America: Creole; South America; and Oceania, an obviously biased system that placed Europeans, more specifically the French, at the top of the geographical hierarchy. This new system

\footnotetext{
87 Of the 1138 plates donated, $\mathbf{5} 80$ were portraits. Only 555 of these were listed in the inventory. The remaining 25 were unaccounted for in the inventory. Only 545 negatives of ethnographic portraits are listed in quai Branly's online catalogue; 10 are unaccounted for.

88 Barthe, "Models \& Norms," 108.

89 I did not have the opportunity to consult the other four inventories in this catalogue and therefore cannot confirm if the plates listed there are part of the Collection Anthropologique series.
} 
reorganized the negatives and omitted the original dates when they were created (indicated on the Collection Anthropologique labels), placing these images into a non-historical context. The inventory also recorded the locations of the negative plates by box number, and the projection numbers. ${ }^{90}$ After the inventory was created, sets of prints were made by the Muséum from Potteau's negatives and marked Collection Potteau ${ }^{91}$ with label information taken from the Collection Potteau inventory.

The Collection Potteau inventory gives an idea of the number of the ethnographic portraits included in the Collection Anthropologique series as well as its geographic breadth. It can be assumed that there were at least 555 plates of ethnographic portraits made by Potteau, including copy negatives from prints by various contributors. Rosseau's negative plates were not included in this inventory as a separate inventory was dedicated to him. ${ }^{92}$ Potteau's negatives of busts, drawings and daguerreotypes, all part of his donation of negatives, were not listed in this inventory. The inventory further suggests that Potteau operated autonomously, even if within the Muséum. He donated his plates to the institution and his donation was acknowledged; his plates, like those of others photographers who made donations to the Muséum, were separated according to maker.

\footnotetext{
90 According to Barthe, the collections were highly circulated for years, "Models \& Norms," 108. Further, according to the Collection Potteau inventory, the negatives were duplicated as projections. Although it is not indicated what type, these were likely lanternslides, a common format for projecting images in the nineteenth century.

91 The majority of images at the BnF from the Musée de l'Homme donation have hand-written labels titled, Collection Potteau and include information from this inventory.

92 There was also a separate inventory for Miot, however copy negatives of his images are included in the Collection Potteau.
} 
In the nineteenth century, Potteau's ethnographic portraits were praised for being fine examples of uniformity ${ }^{93}$ because he was able to produce a coherent series of work through his practice. His protocol for constructing an image was partly borrowed from Rousseau, who had made similar images and likely instructed Potteau in photography, and partly influenced by the aesthetics of studio portraiture at the time. Potteau included at least two views of the subject, a frontal and profile portrait, adopted studio decorations such as drapes and elaborate furniture, instructed his sitter to pose in a specific way and look directly at the camera or to the profile, and presented the images by cropping and mounting them according to established photographic conventions. Although these images were treated as objects of scientific enquiry, Potteau consistently made portraits, with careful attention to lighting, pose, printing and presentation, and remained respectful of his subjects.

In 1863, when Potteau presented a sample of his work to the Société française de photographie, the Supervisor of Photography remarked, "His prints would make very beautiful portraits even if they were not valuable scientific documents." ${ }^{\prime 94}$ In order to understand the dual function of these objects we need to look at the models that Potteau applied in creating them. The presentation methods he used reveal how a portrait was made to serve as a scientific document. By

\footnotetext{
93 Barthe, "Models \& Norms," 108.

${ }^{94}$ As quoted in Barthe, "Models \& Norms," 108.
} 
examining the content of the images and how the views were constructed, we can discuss the photographers approach to the subject in making a portrait.

\section{1 | Image Presentations - A note on nineteenth-century aesthetics}

The set of Collection Anthropologique at the AGO consists of 253 albumen prints mounted on a medium-weight card stock, with printed labels attached in the top left corner on the verso. In some cases, these labels are handwritten in ink or pencil. The prints are cropped to approximately $18 \mathrm{~cm}$ by $12 \mathrm{~cm}$, although a few are much smaller. The original wet collodion glass plate negatives are $27 \mathrm{~cm}$ by $21 \mathrm{~cm}$. The cards on which the images are mounted are $33.5 \mathrm{~cm}$ by $26.5 \mathrm{~cm}$. The prints are systematically centred on the cards with a slightly heavy bottom: a typical presentation for artistic prints, adapted to photographic matting and mounting. This type of presentation is still common for framed photographs to allow space for the photographer's signature or titles.

Potteau's approach to constructing these photographic objects can be analyzed by looking at the various presentation methods he used. The photographs were printed from larger sized negatives and cropped in order to focus in on the subject, but also to construct a portrait. In particular, Potteau applied three presentation methods when cropping and mounting the photographs on the mattboard; the prints were trimmed to oval, rounded or diagonally cut corners. These methods of presentation were borrowed from the traditions of studio portraiture, established a decade earlier and seen in commercial portraiture by Gustave Le 
Gray ${ }^{95}$ Le Gray's artistic presentation was trademarked and shamelessly copied by the competition well into the twentieth century. ${ }^{96}$ The oval and rounded corners were standard shapes of frames; but the shape also influenced the composition of the portrait, focusing on the head and imposing a simple pose, ${ }^{97}$ which was suitable to Potteau's needs. These variations to the presentation method indicate that Potteau's protocol for constructing these images was not systematic and that he adopted established formats used in commercial portraiture.

Fig. 4

\section{Jacques-Philippe Potteau}

260. L'Emir Abd-el-Kader (57 ans) Né à Maskara, (Province d'Oran) (Algérie) Cheveux noirs, mais se rasam la tète tout les deux jours; Yeux bruns, barbe noire avec quelques poils gris. Fils de Moubi Eddin en de Zora, et petit-fils de Moustapha ben Mekta en de Noba. [L'Emir Abd-el-Kader (57 years old) Born in Maskara (Province of Oran) (Algeria) Black hair, but he shaves his head every two days; brown eyes, black beard with a few grey hairs. Son of Moubi Eddin of Zora, and grandson of Moustapha ben Mekta of Noba.] 1865

$15.2 \mathrm{~cm} \times 20.5 \mathrm{~cm}$

Albumen Print from Wet Collodion Negative

Art Gallery of Ontario, Toronto

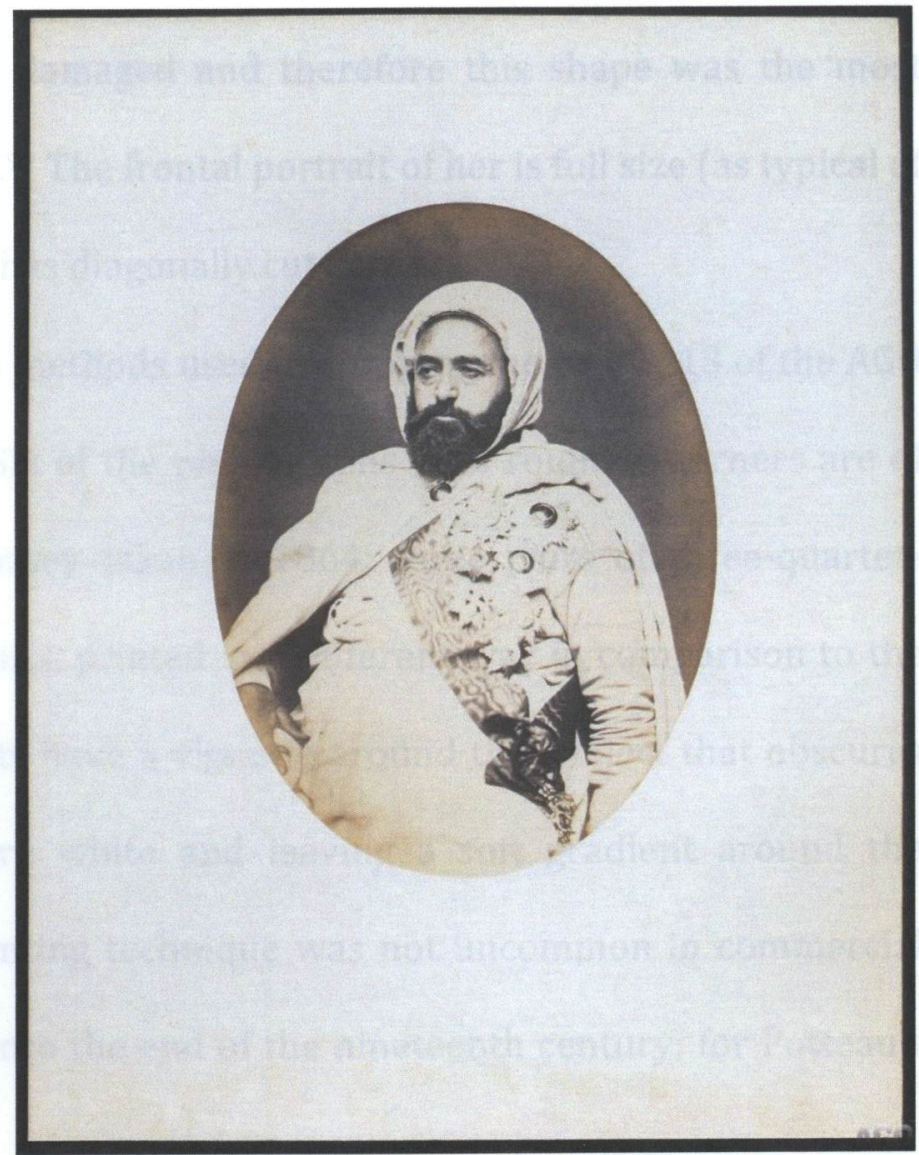

95 Sylvie Aubenas, "Boulevard des Capucines: the glory of the Empire” in Gustave Le Gray 1820-1884, (Los Angeles: J Paul Getty, 2002), 87-98.

96 Ibid, 92.

97 Ibid. 
The oval is the least common presentation method for Potteau prints, as represented by the AGO set and other sets surveyed; however, he seems to have used it for the most prominent of his subjects. Four of the five oval shaped images in the AGO set (including two duplicates), are of L'Emir Adb-el-Kader ${ }^{98}$ (Fig. 4), taken in 1865. Le Gray photographed royalty, aristocracy and important personages visiting Paris, and Potteau chose to distinguish the subject's high rank by applying the oval crop used by Le Gray. The other oval image is a profile portrait of a Chinese woman photographed in 1867 . The print is very small $(9 \mathrm{~cm}$ by $11.8 \mathrm{~cm})$ and it is possible that the negative was damaged and therefore this shape was the most suitable in presenting the image. ${ }^{99}$ The frontal portrait of her is full size (as typical of the other images in the set) and has diagonally cut corners.

Of the three presentation methods used in cropping the prints, 13 of the AGO images have rounded corners. Six of the photographs with rounded corners are of delegates of the Japanese Embassy taken in 1864: three pairs of three-quarterlength frontal and profile portraits, printed in a different way in comparison to the rest of the set. ${ }^{100}$ These portraits have a vignette around the subject that obscures the background, making it pure white and leaving a soft gradient around the circumference (Fig. 5). This printing technique was not uncommon in commercial portraiture and was used well into the end of the nineteenth century; for Potteau's

\footnotetext{
98 L'Emir Adb-el-Kader was an important Algerian Islamic scholar and political leader who led the resistance against French colonial invasion in the nineteenth century. The French defeated his armies and he was exiled in France in from 1847 to 1852, when he was pardoned by Napoleon III.

99 The same print can be found in the Tozzer Library set, presented in the same format. There is no indication that Potteau used different cameras in producing these ethnographic portraits. Emulsion damage on the wetcollodion negative is the most probable cause for the image being cropped in this way; otherwise, it may have been an aesthetic choice.

100 The same prints can also be found in the Tozzer Library set and are both printed and presented in the same manner as those in the AGO set.
} 
purpose, this technique isolated the subject's head. Another six of the rounded photographs are full-length portraits: three of Japanese delegates and three of Cochin-Chinese delegates. The subjects are all wearing ceremonial costumes distinct from the typical dress (kimino or robes) worn in three-quarter-length portraits. The remaining rounded print is also a full-length portrait of a Cochin-Chinese woman taken by Rossier under the direction of Bocourt in Siam in 1862. Once again the artistic presentation can be compared to full-length portraits made in Le Gray's studio, one that he applied to trimming not only portraits, but also landscapes. ${ }^{101}$

Fig. 5
Jacques-Philippe Potteau

184. Kawada Sakami-no-kami (30 ans) né à Yedo - 2e ambassadeur du Taiconne du Japon à Paris. [Kawada Sakami-no-kami (30years old) Born in Edo - $2^{\text {ambassador of the }}$ Shogunate of Japan in Paris.] 1864

$14 \mathrm{~cm} \times 19 \mathrm{~cm}$

Albumen Print from Wet Collodion Negative

Art Gallery of Ontario, Toronto

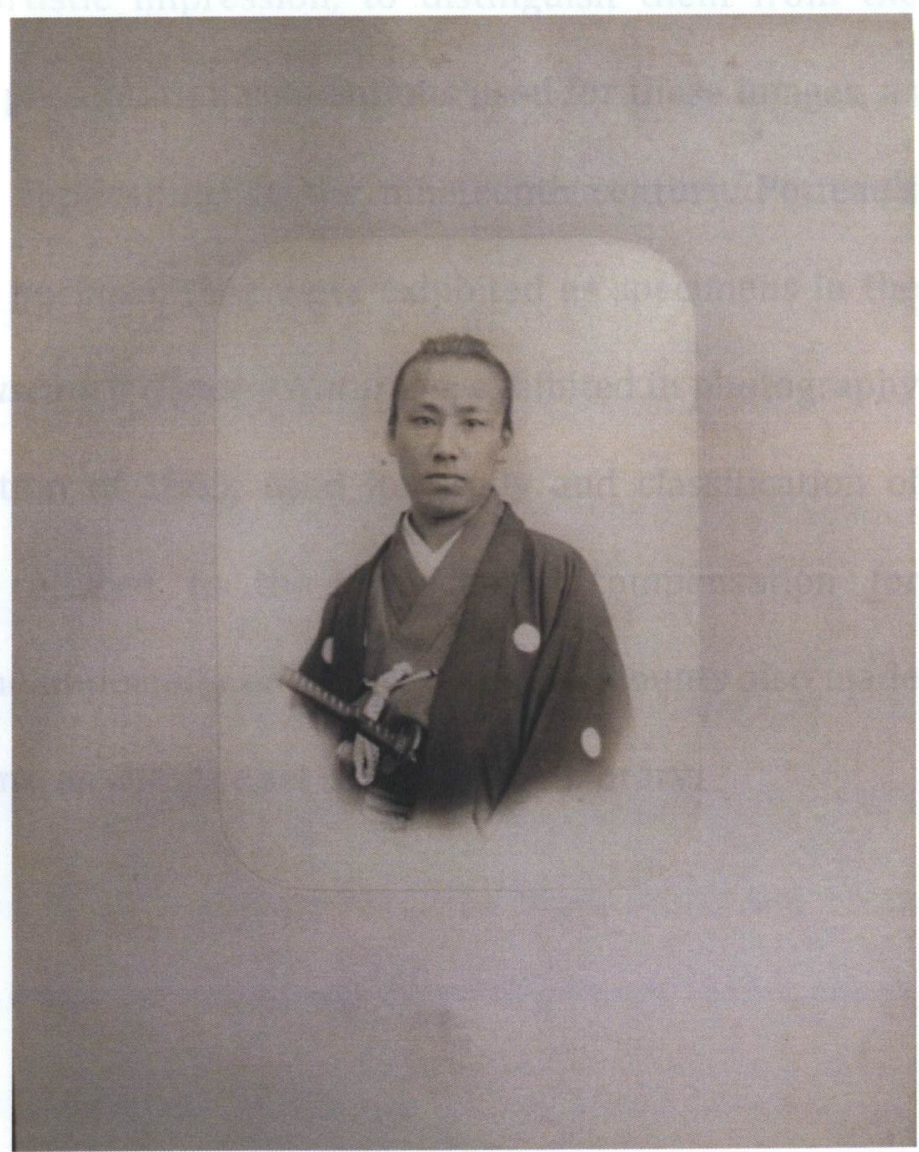

101 See examples in Sylvie Aubenas, Gustave Le Gray 1820-1884, (Los Angeles: J Paul Getty, 2002). 
The remaining 235 photographs in the AGO set have diagonally cut corners. The diagonally cut corners are the most common method of presentation for Potteau prints. ${ }^{102}$ The images printed after 1871 by the Muséum, ${ }^{103}$ like many of those seen at the $\mathrm{BnF}$ and the quai Branly, were cropped to a rectangular shape and are often slightly larger (where the hands of the sitter and studio elements are visible in the frame), indicating that Potteau took much greater care in constructing his prints and distinguishing Potteau prints from later printings of his work.

The size of Potteau images and their respective presentation mounts is also significant. The studios on the Grands Boulevards offered such large portraits to clientele looking for a more artistic impression, to distinguish them from the ubiquitous cartes-de-visite. The presentation conventions used for these images, as well as their size, reflect their applications in the nineteenth century. Potteau's images did not have one single purpose: they were exhibited as specimens in the Anthropology galleries at the Muséum d'Histoire Naturelle; exhibited in photography exhibitions such as RPS exhibition of 1863; used for study and classification of ethnic types; and sometimes offered to the subjects as compensation for participating in the sitting. ${ }^{104}$ The uniformity of the presentation mounts also made them ideal for binding into albums, as with the set at the Tozzer Library.

\footnotetext{
${ }^{102}$ As evidenced by the collections surveyed and suggested by Christine Barthe at the quai Branly. 103 It is unclear who made duplicate prints for the Muséum after Potteau donated his negative plates to the institution.

104 Barthe, "Models \& Norms," 106.
} 


\section{2 | Content - subject not object}

Potteau's approach to making ethnographic portraits was different from that of his contemporaries. He did not accompany any important expeditions, nor did he have the opportunity to travel and photograph people abroad. He organized sittings with official groups who visited the Jardin des Plantes and invited foreigners touring the city to pose in his studio in return for portraits. ${ }^{105}$ The subjects were largely delegates of embassies and were thoroughly identified, not just according to their physical traits, but also their profession and rank; however, some were musicians, domestic servants and people of lower social ranks. Photographing official delegates limited Potteau to making a specific type of portrait as the sitters' presence in his studio was of their own free will. ${ }^{106}$ He could not ask these individuals to perform outside of what they may have considered decent.

By further examining the images we can see how Potteau's protocol for constructing an ethnographic portrait was refined, but was never fully resolved. The social status of his subjects varied as did his studio set up, presentation methods and printing techniques; furthermore, he was unable to consistently record the same information about each subject. After the group of portraits of delegates from the Embassy of Siam in 1861-62, the first official group photographed, Potteau's studio set-up was simplified; the drapery disappeared, the decorations and props were used only sporadically and the subjects no longer posed with studio props, placed in their hand by the photographer.

\footnotetext{
105 Ibid.

106 Jehel, 35.
} 
These images were cropped from what was recorded on the negative plate, which leads us to consider what type of information was included in the print and what was left out, outside of the crop lines. The majority of these images, 225, are three-quarter-length portraits, another convention of the traditional studio portrait, not only in photography, but also in painting. However, for ethnographic study, the convention was applied in order to focus on the face and head, hence also the frontal and profile views, used to give a better sense of the structure of the head, from which observations could be made about cranial capacity or even 'inherent character traits. ${ }^{107}$ In a number of the photographs, the hands are also visible: in a few cases, awkwardly posed in order to show distinguishing features, like long fingernails; in others, subjects are holding a prop that focuses attention on the hand, such as a pen or a cigarette. Jehel's study of this material, which looks predominantly at the delegation from the Siamese Embassy, ${ }^{108}$ concludes that the hands are overwhelmingly visible. ${ }^{109}$ This is true for this group of sitters; however, it is not the case with the rest of the examples in the AGO set. The hands are of course visible on the negative, but they have been trimmed off in many of the prints. ${ }^{110}$ Further on the topic of subject pose, in the frontal portraits Potteau's models are predominantly looking directly at the lens, compared to traditional portraiture, where the subjects are instructed to look just beyond the camera. ${ }^{111}$

\footnotetext{
107 Martin S. Staum, Labeling People: French Scholars on Society, Race and Empire, 1815-1848. Montreal: McGillQueen's University Press, 2003), 176.

${ }_{108}$ According to information gathered from the labels, there were 16 subjects from this delegation.

109 Jehel, 40.

110 The original negatives are $27 \mathrm{~cm} \mathrm{x} 21 \mathrm{~cm}$; the images are only approximately $18 \mathrm{~cm} \mathrm{x} 12 \mathrm{~cm}$, therefore a portion of the image has been cut off. I have seen a number of prints that were not cropped as tightly and the hands are visible.

111 In a sample of 100 cartes-des-visite from the same period, only 12 subjects are looking directly at the camera, most of them children.
} 
The studio setup in the group of portraits of the Siamese sitters is elaborate and includes drapes in the background, a table with props such as books and an embellished high-back chair. Another recurring element visible in the full-length portraits is a decorative tile-patterned carpet, which is used on the floor of the studio, covering what appears to be an elevated podium. These elements are useful in identifying photographs made in Potteau's studio (Fig. 6). However, the full studio setup, typical of a commercial portrait studio at the time, is visible only in images of the Siamese delegation and partly (without the drapes) for seated full-length portraits of the Cochin-Chinese group, photographed in $1863 .{ }^{112}$ Potteau had carefully considered how to best make an ethnographic portrait versus a traditional one; he had also considered that he had to treat his subjects, many of them honourable dignitaries, with the level of respect that their presence in his studio commanded. ${ }^{113}$

After 1863, it appears that Potteau adopted a more sterile studio set up with a consistently white or plain background and removed the furniture with the exception of several different embellished chairs, which are sometimes visible in the image. The subjects continued to pose with props, but only those that were part of their attire, such as swords, and not ones deliberately placed in their hand by the photographer. Potteau was trying to implement a more objective view of his subjects; this is also evident in the evolution of the label information that he collected (discussed below).

\footnotetext{
112 It is possible that these elements remain present on the negative and have been cropped out of the image; however, as I was unable to access the negatives, and cannot confirm this.

113 There are a number of images taken by Potteau in 1860 and included in the Collection Anthropologique series, where African subjects are posed shirtless against a plain background, a much more objectifying view compared to the photograph of members of official groups.
} 
Fig. 6

Jacques-Philippe Potteau

67. Munhannaroug (31 ans) Secrétaire d'ambassade né à Bangkok (Siam) [Munhannaroug (31 years old) Secretary of the embassy, born in Bangkok (Siam)], 1861.

$13 \mathrm{~cm} \times 18 \mathrm{~cm}$

Albumen Print from Wet Collodion Negative

Art Gallery of Ontario, Toronto

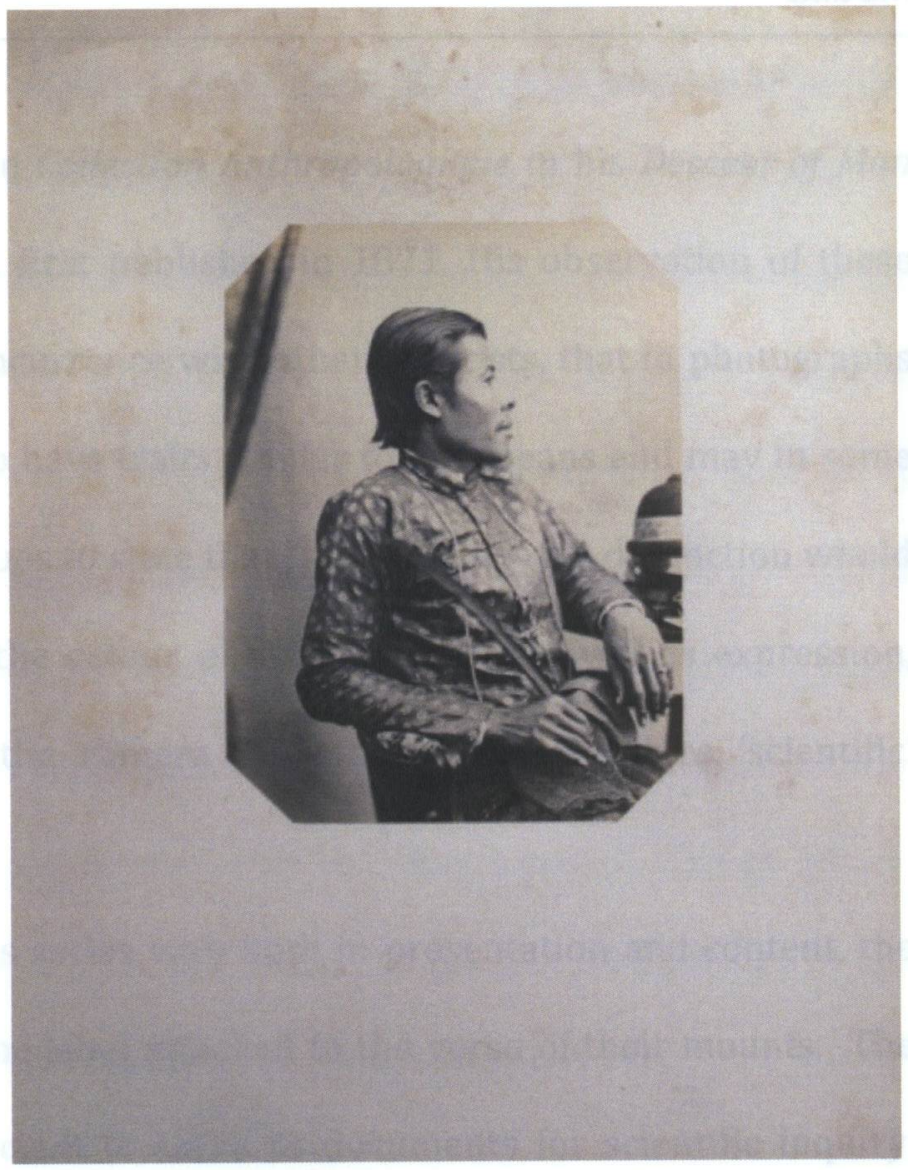

This practical examination of Potteau's work allows us to consider the nuances of his practice. Potteau's modus operandi allowed him to make marketable commercial products and his relationship to the Muséum secured his venture financially. Armand de Quatrefage was supportive of Potteau's production and used his photographs as specimens to build the Anthropology Collection at the Muséum. This connection to the institution also gave Potteau an authority among other groups who purchased and used his images. He distributed his work among societies with anthropological and ethnographic interests as well as artistic ones, such as the SFP. 
Charles Darwin speaks about the Collection Anthropologique in his Descent of Man and Selection in Relation to Sex, first published in 1871. His observation of these images leads him to state, in concurrence with other theorists, that in photographs people of different races seem to have traits similar to Europeans and may in some cases "pass" for some. He continues to state that "if seen alive" the distinction would be much more evident due to the colour of skin and hair as well as expression, alluding to the limitations of the camera in being able to produce 'scientific' documents. ${ }^{114}$

While photographs in this series vary both in presentation and content, the unifying factor among them is the label attached to the verso of their mounts. The images themselves were insufficient to serve as documents for scientific inquiry, which draws inferences from quantifiable information; therefore, quantifiable data about the subject was collected to supplement the images. The images were also limited by the medium; albumen prints in all of their shades of beige and brown were still monochromatic. They could not entirely inform the viewer and therefore the photographer needed to record information to compensate for that which was unknown. This process of documentation made the Collection Anthropologique a coherent whole, chronologically organized according to a protocol established by the photographer. There are several indications that Potteau was responsible for the labelling and organization of this series.

114 Darwin, 195. 
1 | Labelling Objects: portrait or specimen

There are two different sizes of labels on the verso of the AGO photographs; the standard is $3 \mathrm{~cm}$ by $8 \mathrm{~cm}$ and the large version is $6.5 \mathrm{~cm}$ by $8 \mathrm{~cm}$. The larger labels are rare but provide more biographical and sometimes anecdotal information about the subject than the smaller labels. Each label bears the title Collection Anthropologique du Muséum de Paris and is written in French. They follow a sequential numbering system and each number in the system is assigned to one of the subjects portrayed, as explained above. Thereafter, the information recorded varies. In most cases, the subject's name is recorded. If the name is not known, the subject's position or rank is recorded. In the most obscure cases, often with the images contributed by others, only a basic subject description is provided, e.g. 276. Young Girl, Japanese or 83. Young Siamese, (Fig. 7) that always includes the subject's ethnicity.

Fig. 7

Jacques-Philippe Potteau

Small label mounted on verso of image mount Art Gallery of Ontario, Toronto

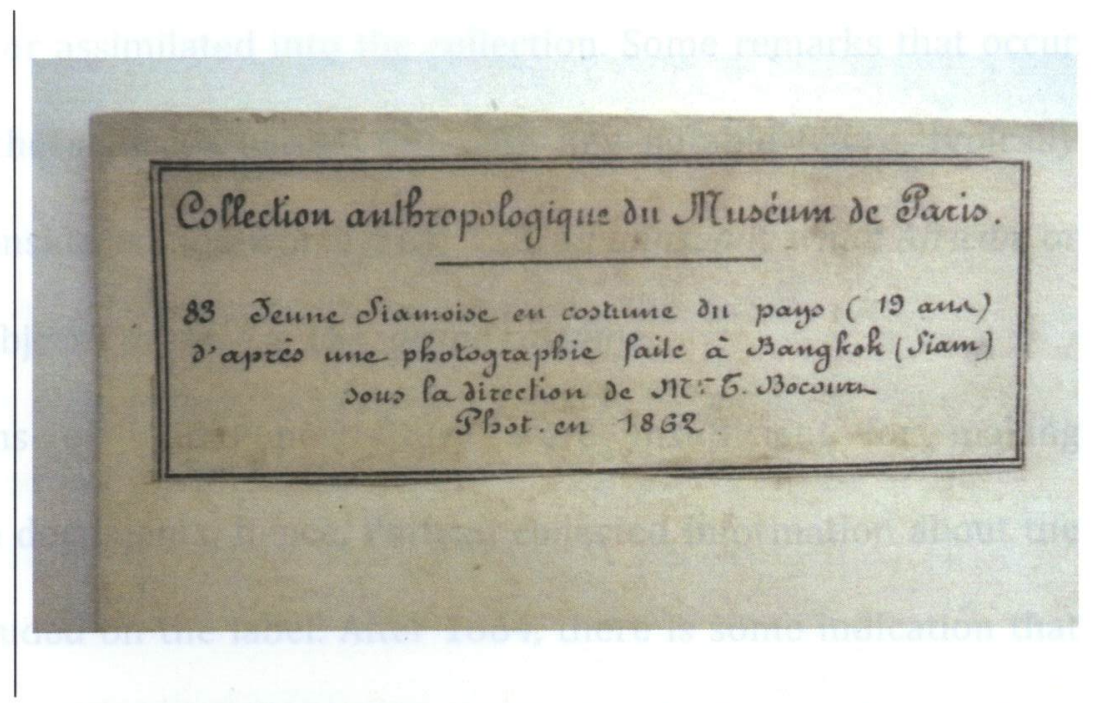

Next, the subject's age is recorded in brackets e.g. (xx years), sometimes this figure is represented with more precision, e.g. 209. Mi-yaké Hidzou (16 1/2 ans); this latter format is generally used for younger subjects. In a few cases, usually for 
European subjects, the birthdates are recorded. In some cases, the age has been filled in after the label was printed, in pencil; it is difficult to determine who may have filled it in and whether it is valid. Twenty of the labels do not indicate the subjects' ages at all; most often these are on images that have been assimilated into the series. ${ }^{115} \mathrm{~A}$ few examples have labels that have been crossed out in pencil, implying that the wrong label was likely attached.

The information that follows is not entirely systematic and includes one or more of the following details: place of birth (city, province, country or continent), parentage and parents' ethnic origins or place of birth, profession or rank (especially for military subjects), affiliation (embassy or delegation), place that the photograph was taken, by whom, who is responsible for bringing it from abroad (in the case of contributed images, where the photographer is not identified) and the year that it was taken or assimilated into the collection. Some remarks that occur sporadically, such as the subject's association with any notable figure, typically European, any traits considered noteworthy, e.g. 128. an unusually white African, or comments about the subject's dress, e.g. 151. grand costume.

The conventions of studio portraiture were insufficient for making standardized, objective documents; hence, Potteau collected information about the subjects, which he included on the label. After 1864, there is some indication that there was a need for more precise information, as the height, hair and eye colour, began to be recorded systematically with one exception. The label attached to the portrait of L'Emir Abd el-Kader, discussed above, provides detailed information copy negatives. The label information on these images was likely provided by the contributor. 
about the colour of the subject's eyes, hair and beard, but not his height. It can be assumed that Potteau was unable to obtain this information when photographing this high-ranking subject because he would have had to ask to measure the subject, which the subject would have likely considered inappropriate. The choice of subjects, dignitaries, official delegates and groups, presented a challenge in obtaining data (as in the example above) suitable for scientific enquiry; Potteau nevertheless recorded that which he was able to obtain on the label.

The first indication that Potteau was responsible for writing the labels is one label in the AGO set, which is written in the first person:

“214. Hayasi kankai (21 ans) né à Yedo, Etudiant en médecine à La Haye (Hollande) Ce Japonais que j'ai photographié par un très mauvais temps a la peau aussi blanche qu'un Européen très blanc Phot. en 1864." [214. Hayasi kankai (21 years old) born in Edo, student of medicine in The Hague (Holland). This Japanese (male) whom I photographed in very bad weather conditions has skin as white as the whitest European. Phot[graphed] in 1864.]

The for this same label in the Collection Potteau inventory appears as:

Hayasi kankai 21.. ans.. né à Yedo, Etudiant en médecine à La Haye (Hollande) Ce Japonais photographié par un très mauvais temps, a la peau aussi blanche qu'un Européen très blanc. Face [Hayasi kankai.. 21 years old.. born in Edo, student of medicine in The Hague (Holland). This Japanese (male) photographed in very bad weather conditions has skin as white as the whitest European. Frontal]

The original subject number, the year the photograph was taken and the first person reference by the photographer, have all been omitted. But the Muséum considered Potteau's commentary important and kept records of his observations in the 
Collection Potteau inventory. It is known that Potteau chose his subjects and organized sittings, ${ }^{116}$ and, as suggested here, it can be inferred that he gathered information about them (the example of Kader indicates his limitations in doing so); therefore, it is probable that he also wrote the original labels, which were then printed and attached to duplicate images. ${ }^{117}$

Finally, the images (according to their respective labels) were not ordered chronologically by their date of creation, indicating that the organizational system was established after some part of the images had been made, potentially as late as 1864. If Potteau was in fact responsible for the entire production and organization of these photographic objects and the Muséum purchased his prints, he can be classified as photographer-anthropologist, a role that Jehel has defined for photographers making anthropological images at this time. ${ }^{118}$ Potteau made these photographs independently, which can be seen as reflections his interest in the field. His observations and records were all important to the value of these photographs as scientific specimens; the Muséum retained the recorded information in their catalogue (Collection Potteau inventory) and the images were widely used in ethnographic studies. ${ }^{119}$

\footnotetext{
116 Jehel, 36.

117 Some of the labels on the verso of the Collection Anthropologique prints made by Potteau were hand written. The handwriting has not been identified. The Collection Potteau images did not have printed labels; these were all handwritten presumable by a Muséum employee, as the handwriting is consistent.

118 Jehel, 5.

119 The Muséum d'Histoire naturelle reproduced Potteau's negatives in print and projection formats, probably lantern slides. The reproductions were widely circulated according the "Cahier des sorties," which recorded outgoing collection material at the institution. Barthe, "Models \& Norms," 108.
} 
2 | Uncut Labels: the in between

The AGO set of the Collection Anthropologique series was accompanied by a set of ten sheets of uncut labels related to the material. The sheets begin with label one, subject number one and continue sequentially until number 178 at the top of page 8 (Fig. 8). Sheet eight is a random selection of labels for photographs of various kinds of objects, with different label titles including: Société Anthropologique de Paris, Collection d'anatomie comparée, Collection du Muséum d'Histoire naturelle, Collection du Muséum de Paris, Collection de l'École de Pharmacie. From this sheet of uncut labels, it can be inferred that if Potteau wrote the labels for the other institutional collections, he also made photographs for them.

The majority of the images, both those in the AGO set and those identified by the uncut labels, were not credited to a photographer; however, Christine Barthe has identified them as Potteau's. ${ }^{120}$ They have been previously identified and catalogued in the Collection Potteau and can be cross-referenced with this inventory of negatives. Those that were made by Rousseau were labelled as such, "Phot. par M. Rousseau." Those made by or contributed by others were also labelled as such. This suggests that since Potteau wrote the labels, he did not need to acknowledge the photographer on his own work, but only credited the work of others.

Apart from the labels for various institutions, sheet eight exhibits two other anomalies: first, there are three labels that bring into question the relationship between Rossier and Bocourt, and second, there are two labels that describe photographs of human skulls. The photographs in the Collection Anthropologique

\footnotetext{
120 Barthe, "Models \& Norms"; Survey of sets at the BnF and quai Branly.
} 
series taken by Rossier are labelled as 'under the direction of M. F. Bocourt' and do not credit Rossier as the photographer. However, on this sheet, there are three labels without the Collection Anthropologique title (indicating that these are not part of the series) for photographs given by Bocourt (as indicated on the label), which directly credit Rossier as the photographer. Why was Rossier's name not included on the Collection Anthropologique photographs? Firmin Bocourt, an artist and naturalist in his own right, was chosen to go to Siam to receive a gift of animals from the Siamese King. ${ }^{121}$ He was also mandated by the Muséum to collect zoological and botanical specimens. ${ }^{122}$ The images that are credited to Rossier are of monuments in Bangkok, which were likely photographed on his own initiative and gifted to or purchased by Bocourt, whereas those photographed specifically to meet the mandate of the Muséum, possibly for inclusion in the series, were orchestrated by Bocourt and he is therefore given credit for their creation, despite the fact that they were taken by Rossier. Jehel states that these are similar to Potteau's images, ${ }^{123}$ but I would argue that some of them are different. The photographs of the Siamese King are in line with Potteau's perspective and composition; however, those of the young women, half nude and posed suggestively on an exotic animal skins, verge on the exotic and reflect Bocourt's own artistic intentions.

The second deviation from the systematic chronology of the other sheets of labels that list ethnographic portraits are two labels with the Collection Anthropologique title, label numbers 347 and 1603 (the highest number in the series

\footnotetext{
121 Henri Milne Edwards "Rapport de M Bocourt a Siam," Comptes rendus hedbomadaires de l'Academie des Sciences, Paris, Mallet Bachelier, 1863, t.57, p.313 as quoted in Jehel, 38.

122 Jehel, 38.

123 Ibid.
} 
I have seen), which identify images of skulls. The objects identified by these labels are different from the portraits, but not unlike other objects included early in the series, i.e label \#4 is for a drawing of the Hottentot 'Venus' by Wally made in 1815.124 Label \#1603, is the same subject's skull. Potteau's donation included 256 negative plates of skulls ${ }^{125}$ and it is likely that these constituted part of the Collection Anthropologique series. The labels do not record the date that the photographs were taken, but the late label numbers indicate that the photographs were produced later. These two labels were also the first indication that a variety of objects were eventually photographed for the Collection Anthropologique series, possibly with the intention of preserving them, as was initially advocated with the introduction of the practice of photography in the Muséum.

The labels are very important to the series, not only because they identify the subject of each photograph, but also because they contribute to the creation of a scientific document. The text legitimized the image in the scientific domain, serving as secondary and quantifiable evidence or so was the intention. It is fitting that Potteau should write the labels if he was taking the photographs. Without the supplementary information, the portraits would have little 'scientific' value because they would present too many unknown variables.

\footnotetext{
${ }^{124}$ Jehel suggests that the Hottentot Venus, Saartjie Baartman, came to symbolize the "primitive humanity," as quoted in Jehel, 27. Her notoriety and presence of her remains at the Muséum made her an important subject for inclusion in the series.

125 Barthe, "Models \& Norms," 108.
} 
Fig. 8

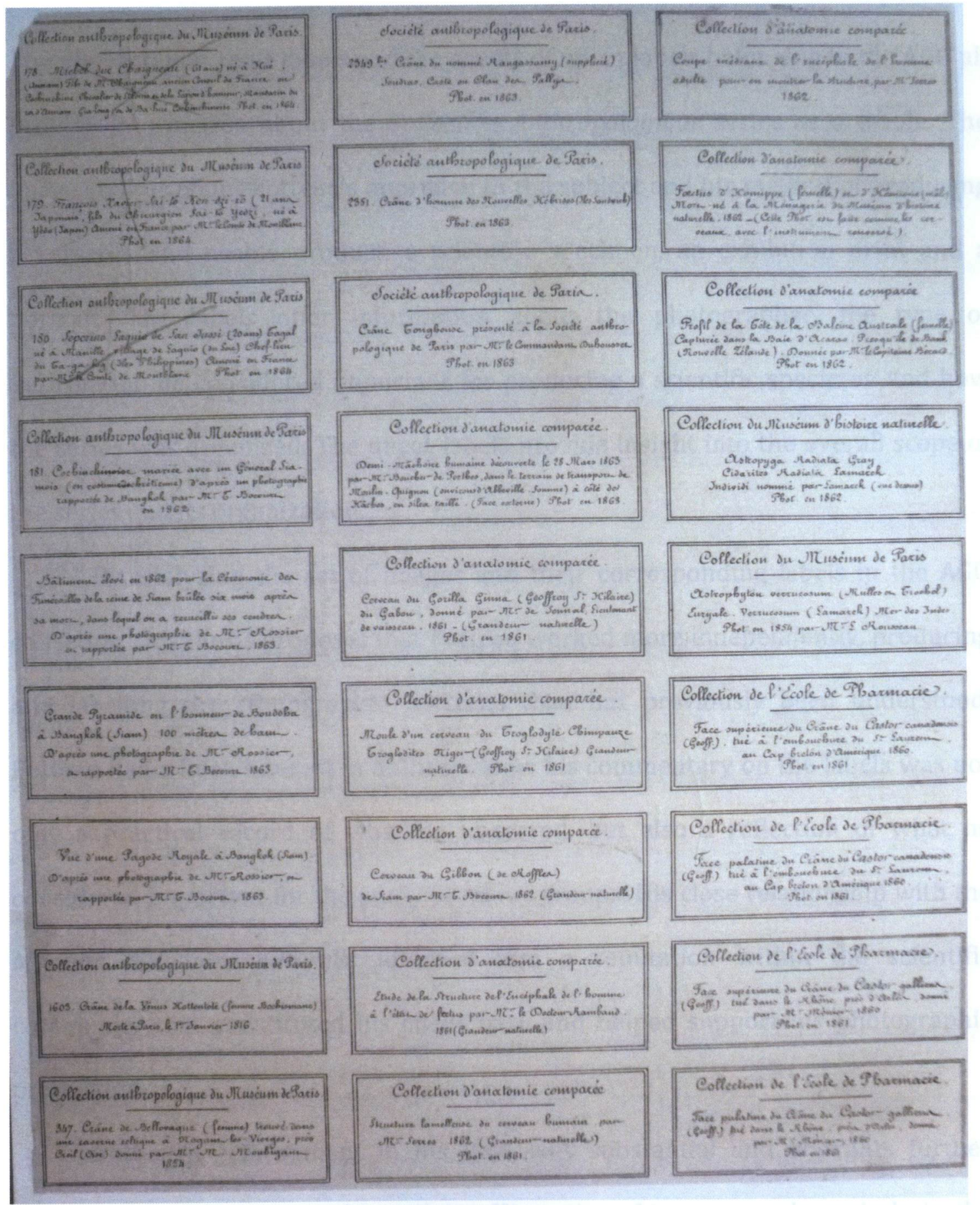

Uncut sheet of labels \#8

Art Gallery of Ontario, Toronto 
The photographs, their labels and the sheets of uncut labels belonging to the AGO all provide information about the Collection Anthropologique series as a whole. The images tell us about Potteau's approach to the subject and his method of producing a versatile and usable product: a scientific specimen, an exhibition print and a portrait. The labels offer information about the photographer, the type of information he considered important for producing a scientific specimen and how the series was organized. The uncut labels provide insight into the overall scope of the series and its organization.

By analyzing the set of images and their corresponding labels in the AGO collection, this thesis proposes that Potteau worked more independently, producing and labelling the ethnographic portraits than has previously been understood. Potteau had a keen interest in anthropology; his commentary on the labels was not only a practical record of what he observed, but also a reflection of what he considered important for the study of ethnic groups. His close relationship with the Muséum d'Histoire naturelle afforded him a reputation within the scientific community that constituted his client base and helped support his photographic production.

Potteau's achievement in his field was substantial and warrants further research into his photographic activity. His series of images, made entirely in the studio and without ever leaving Paris is unique in contrast to the intrusiveness of contemporaneous anthropological photographs made abroad. His approach to the 
subject was sensitive and it is therefore no surprise to see some of his subjects smiling coyly, like children in a yearbook picture. Today, these images are no longer seen as scientific specimens. They do not harness any scientific truth about human beings, as we have long ago rejected this type of subjective viewing of different ethnicities. Many anthropological photographs, including those at the AGO, have been reinterpreted as artworks, representative of the photographer's aesthetics far more than the subject's physiognomy; others are used for historical reference and others still serve as examples of early visual anthropology.

Photography was not an ideal tool for building the anthropological typologies that the Muséum sought to create because it did not reveal anything beyond the surface of the subject. Nevertheless by 1930, the Musée de l'Homme had inherited nearly 200,000 photographs in this vein from the Muséum d'Histoire naturelle. ${ }^{126}$ There was a disjunction between the purpose and approach to making anthropological photographs. On the one hand, ethnographic portraits were a means of representing individual 'live subjects' in the museum; but the way that they were photographed, removed from their context and placed in a studio setting, made the subject representative of an entire culture.

There are still many unanswered questions about Potteau's terms of employment at the museum and whose interests and intentions were being played out in the construction of this series. The support of Armand de Quatrefage and his

126 Jehel, 4. 
pursuits as head of the Human Anatomy and Natural History laboratory was instrumental in Potteau's continual production of material. ${ }^{127}$

The AGO set has been thoroughly investigated and documented, making the material accessible to the institution staff and hopefully gallery patrons in the future. The proper identification of each individual image has added not only to its value as an art object in a public institution, but also to the general knowledge about the series and the photographers.

127 Quatrefage uses Potteau's images in his Histoire générale des races humaines: introduction a l'étude des races humaines (Paris 1887-89), Barthe, “Models \& Norms," 106. 
Database

In order to organize the information available from the image set and labels at the AGO, I constructed a database in FileMaker Pro. The primary purpose of the database was to accurately and completely document the set in the AGO collection, for ease of access and use by the museum [AGO]. The secondary purpose was to extract statistical data and analyze the image content and label information in order to make inferences for the purposes of this study.

The database was divided into three tables: object, image and label. The object table, used primarily for identification of images, contains general information fields about the object, including: 'object id number', 'photographer', 'date', 'title', 'image size', 'medium' and 'process'. The 'photographer', 'medium' and 'process' fields include a list of controlled values, meaning that the user can only choose from the values provided and cannot input information outside of these preset values. For example, the 'photographer' field consists of three choices: 'Jacques Philippe Potteau', 'Pierre-Joseph Rossier' and 'other'. The control lists ensures that data is consistent and helps prevent errors in spelling, etc.

The image table contains information about the print itself as well as image content. I used this information to study image presentation and content. Each field has a number of controlled values. The type of presentation is expressed in the 'shape' field, which is limited to: 'oval', 'rounded', 'cut' or 'rectangular' corners and other. The subject's 'pose' is expressed as: 'frontal', 'profile', 'full-length seated', 'fulllength standing'. The image 'background' is divided into: 'studio', which includes any 
type of background decoration; 'plain', which is generally a neutral or grey background without studio props; 'outdoors', which I chose versus 'in the field' or 'natural environment' as I have not seen any such images in the series, and finally, 'other'. I used a separate field to note any specific props used by the photographer or the subject. This field is not controlled and can accept unrestricted user input, e.g. fan, pen/ink or (headrest?), which gives clues about the sitter or the photographer's process. I set up a field of three radio buttons titled 'hands', in order to determine whether the hands of the sitter were 'visible,' 'partially visible' or 'cropped' out of the image, and another set of radio buttons to account for 'image relationships': 'one of one', 'one of two', 'two of two', and 'other'. The image table includes one other free field titled 'markings', which denotes any markings or inscriptions, such as stamps or writing exclusive of the label. It is not particularly applicable to the set found at the AGO as none of the mounts have markings save the label; however, most of the photographic objects from the Collection Anthropologique found at the $\mathrm{BnF}$ and the quai Branly are marked in some way.

The final table specifies the information found on the label and was used to record subject groups and relationships, geographical scope and specifics about recorded information, such as hair and eye colour. The fields in this table include: 'subject number', 'name', 'age', 'origin', 'group', 'description' and the 'label authority'. The 'subject number' refers to the number assigned to the subject according to the original label. The 'subject origin' field allows for statistical analysis of the ethnicities included in the series. The 'subject group' field is a controlled field that further groups the subjects together based on their relationship to other subjects. 
This is generally most applicable to delegations and embassy representatives that Potteau photographed. The control list includes: 'Algerian Military', 'Embassy of Cochin-China', 'Chinese Embassy', 'Japanese Embassy', 'Siamese Embassy' and 'Under M. F Bocourt' (the images attributed to Pierre-Joseph Rossier) and 'other', which accounts for any copy images included in the collection, by other photographers or contributors. Subject description includes other specific information recorded about the subject such as, height, hair and eye colour. The 'label authority' denotes the source of the label, whether a printed label titled "Collection Anthropologique du Muséum de Paris" is attached to the verso or a hand-written one. Finally, a thumbnail image of the object is attached to each record for reference.

The user can search each input field and generate form, list and table views of the photographic objects. The database can also be used to reorder the images in date sequence. This is important because the series was not ordered chronologically, which suggests that it was complied at a later point and not in 1855 , the date of the earliest negative by Rousseau included in the Collection Anthropologique. It seems that these early negatives were absorbed into an organizational system and titled "Collection Anthropologique du Muséum de Paris" as late as 1864 , after which time the numbering system on the labels corresponds with the chronology of the negatives. 
In order to search for anomalies among the prints in the AGO set, I conducted a search by year. When I got to 1867, I discovered that one of the images, (Fig. 9)

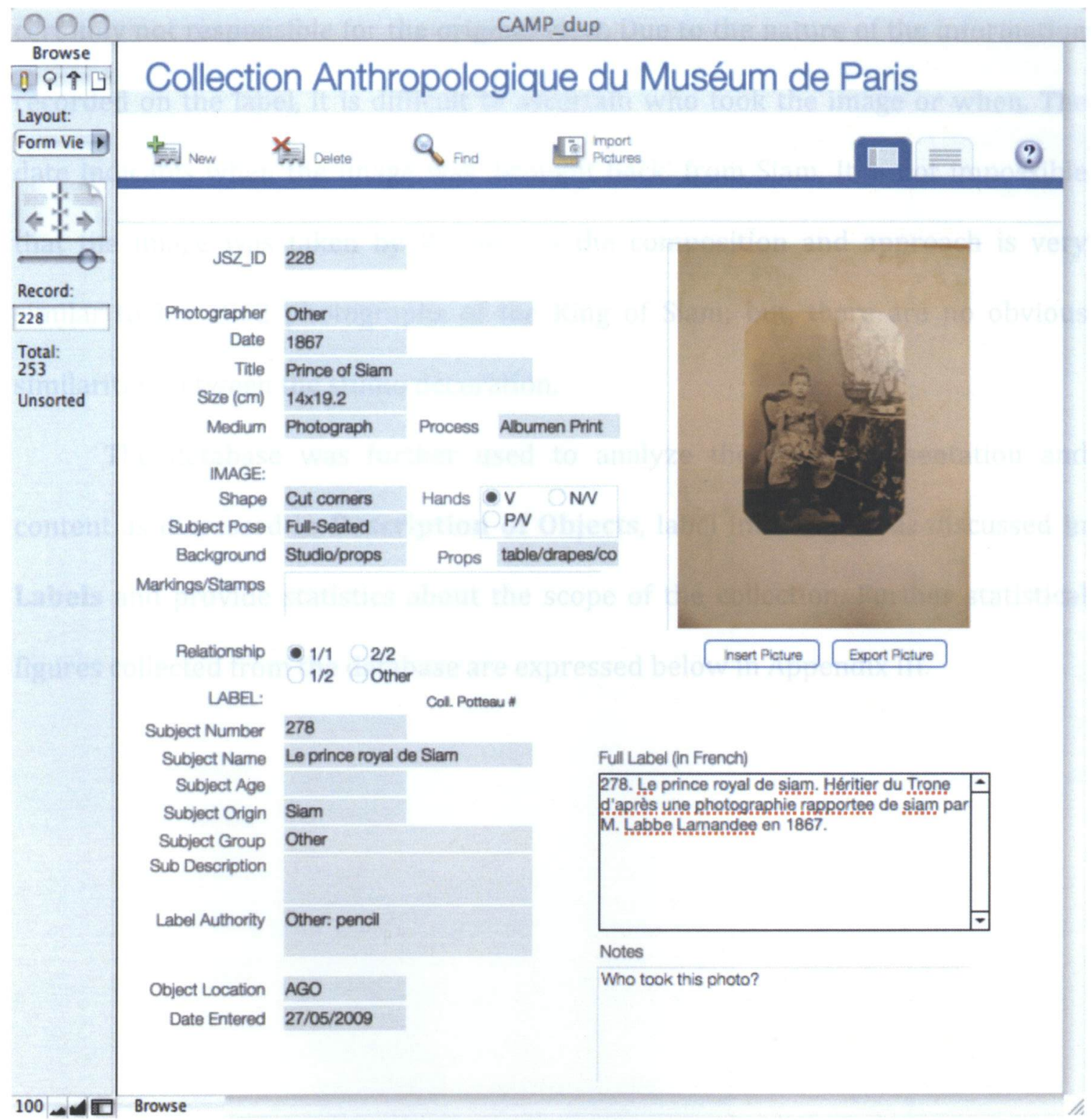

Fig. 9 Image of database created for this investigation.

label \#278 Le prince royal de Siam [The Royal Prince of Siam], had been wrongly attributed to Potteau, according to the spreadsheet provided by the donor. The label indicates that the photograph had been brought back from Siam by L'abbé 
Larnandie in 1867. As with other photographs contributed by others, Potteau made a copy negative of the image to include in the series; ${ }^{128}$ however, he was most certainly not responsible for the original view. Due to the nature of the information recorded on the label, it is difficult to ascertain who took the image or when. The date indicates when the image was 'brought back' from Siam. It is not impossible that the image was taken by Rossier, as the composition and approach is very similar to his 1862 photographs of the King of Siam; but, there are no obvious similarities between the studio decoration.

The database was further used to analyze the image presentation and content as discussed in Description of Objects, label information as discussed in Labels and provide statistics about the scope of the collection. Further statistical figures collected from the database are expressed below in Appendix III.

128 Christine Barthe, in conversation with the author, June 16 2009. 
Figures presented here relate to the 253 photographic objects in the AGO set (duplicates are counted once) + data from the uncut labels (\#1-231, duplicates are included):

Number of plates by photographer:

Lacaze-Duthiers, Henri de

Miot, Paul-Émile

M. L. d'Eichtal

M. le Comte de Montblanc

Potteau, Jacques-Philippe*

Rossier, Pierre-Joseph (Bocourt)

Rousseau, Louis

Other

Number of plates by Potteau, per year:*

1857

1859

1860

1861

1862

1863

1864

1865

1866

1867

1868

1869

\begin{tabular}{|c|c|}
\hline Objects & Uncut Labels \\
\hline- & 6 \\
\hline- & 4 \\
\hline- & 7 \\
\hline- & 5 \\
\hline 244 & $192 * *$ \\
\hline 7 & 12 \\
\hline- & 18 \\
\hline 1 & - \\
\hline 0 & 1 \\
\hline 0 & 1 \\
\hline 0 & 11 \\
\hline 24 & 21 \\
\hline 2 & 23 \\
\hline 104 & 76 \\
\hline 62 & 50 \\
\hline 10 & - \\
\hline 16 & - \\
\hline 6 & - \\
\hline 0 & - \\
\hline 20 & - \\
\hline
\end{tabular}

* Includes all labels without attribution to others. Labels for images taken in 1857 and 1859 have also been attributed to Potteau in the Collection Potteau inventory.

** Label set is not complete: earliest unattributed entry is 1857 , last entry is in 1864 . 
The following is a list of images of the Collection Anthropologique set in the collection at the Art Gallery of Ontario, used in this study as a representative sample

of the series.

\begin{tabular}{|c|c|c|c|c|}
\hline ID & Date & Photographer & Label & Subject Name \\
\hline \# & & & \# & \\
\hline 1 & 1863 & Potteau, Jacques-Philippe & 57 & Mohamed Ben Maktar \\
\hline 2 & 1863 & Potteau, Jacques-Philippe & 57 & Mohamed Ben Maktar \\
\hline 3 & 1862 & Potteau, Jacques-Philippe & 63 & Hluang Indimontry \\
\hline 4 & 1862 & Potteau, Jacques-Philippe & 63 & Hluang Indimontry \\
\hline 5 & 1861 & Potteau, Jacques-Philippe & 64 & $\begin{array}{l}\text { Kloom } \\
\text { Mahasiddihwaharm }\end{array}$ \\
\hline 6 & 1861 & Potteau, Jacques-Philippe & 64 & $\begin{array}{l}\text { Kloom } \\
\text { Mahasiddihwaharm }\end{array}$ \\
\hline 7 & 1861 & Potteau, Jacques-Philippe & 66 & Naïlbim \\
\hline 8 & 1861 & Potteau, Jacques-Philippe & 66 & Naïlbim \\
\hline 9 & 1861 & Potteau, Jacques-Philippe & 67 & Munhannaroug \\
\hline 10 & 1861 & Potteau, Jacques-Philippe & 67 & Munhannaroug \\
\hline 11 & 1861 & Potteau, Jacques-Philippe & 68 & Naidan \\
\hline 12 & 1861 & Potteau, Jacques-Philippe & 68 & Naidan \\
\hline 13 & 1861 & Potteau, Jacques-Philippe & 69 & Chune \\
\hline 14 & 1861 & Potteau, Jacques-Philippe & 69 & Chune \\
\hline 15 & 1861 & Potteau, Jacques-Philippe & 71 & Naipia \\
\hline 16 & 1861 & Potteau, Jacques-Philippe & 71 & Naipia \\
\hline 17 & 1861 & Potteau, Jacques-Philippe & 72 & Naifak \\
\hline 18 & 1861 & Potteau, Jacques-Philippe & 72 & Naifak \\
\hline 19 & 1861 & Potteau, Jacques-Philippe & 73 & Munnarapakadi \\
\hline 20 & 1861 & Potteau, Jacques-Philippe & 73 & Munnarapakadi \\
\hline 21 & 1861 & Potteau, Jacques-Philippe & 74 & Munchindarak \\
\hline 22 & 1861 & Potteau, Jacques-Philippe & 74 & Munchindarak \\
\hline 23 & 1861 & Potteau, Jacques-Philippe & 75 & Khounraxassoinbar \\
\hline 24 & 1861 & Potteau, Jacques-Philippe & 75 & Khounraxassoinbar \\
\hline 25 & 1861 & Potteau, Jacques-Philippe & 76 & Naider \\
\hline 26 & 1861 & Potteau, Jacques-Philippe & 77 & Naisoung \\
\hline 27 & 1861 & Potteau, Jacques-Philippe & 78 & Bharul \\
\hline 28 & 1861 & Potteau, Jacques-Philippe & 78 & Bharul \\
\hline 29 & 1862 & Rossier, Pierre Joseph & 80 & King of Siam \\
\hline 30 & 1862 & Rossier, Pierre Joseph & 81 & King and Queen of Siam \\
\hline 31 & 1862 & Rossier, Pierre Joseph & 82 & Young Siamese Girl \\
\hline 32 & 1862 & Rossier, Pierre Joseph & 83 & $\begin{array}{l}\text { Young Siamese in } \\
\text { Costume }\end{array}$ \\
\hline 33 & 1862 & Rossier, Pierre Joseph & 87 & Pégouan Type \\
\hline 34 & 1862 & Rossier, Pierre Joseph & 88 & Laotian Type \\
\hline 35 & 1863 & Potteau, Jacques-Philippe & 117 & Djellali Ben Selimen \\
\hline 36 & 1863 & Potteau, Jacques-Philippe & 117 & Djellali Ben Selimen \\
\hline 37 & 1863 & Potteau, Jacques-Philippe & 118 & Mohamed ben Miloud \\
\hline 38 & 1863 & Potteau, Jacques-Philippe & 118 & Mohamed ben Miloud \\
\hline
\end{tabular}

\section{Subject Group}

Algerian Military

Algerian Military

Siamese Embassy

Siamese Embassy

Siamese Embassy

Siamese Embassy

Siamese Embassy

Siamese Embassy

Siamese Embassy

Siamese Embassy

Siamese Embassy

Siamese Embassy

Siamese Embassy

Siamese Embassy

Siamese Embassy

Siamese Embassy

Siamese Embassy

Siamese Embassy

Siamese Embassy

Siamese Embassy

Siamese Embassy

Siamese Embassy

Siamese Embassy

Siamese Embassy

Siamese Embassy

Siamese Embassy

Siamese Embassy

Siamese Embassy

Under M. F. Bocourt

Under M. F. Bocourt

Under M. F. Bocourt

Under M. F. Bocourt

Under M. F. Bocourt

Under M. F. Bocourt

Algerian Military

Algerian Military

Algerian Military

Algerian Military 


\begin{tabular}{|c|c|c|c|c|}
\hline 39 & 1863 & Potteau, Jacques-Philippe & 119 & $\begin{array}{l}\text { Mohamed ben } \\
\text { Karrouche }\end{array}$ \\
\hline 40 & 1863 & Potteau, Jacques-Philippe & 119 & $\begin{array}{l}\text { Mohamed ben } \\
\text { Karrouche }\end{array}$ \\
\hline 41 & 1863 & Potteau, Jacques-Philippe & 120 & Mohamed ben Attab \\
\hline 42 & 1863 & Potteau, Jacques-Philippe & 120 & Mohamed ben Attab \\
\hline 43 & 1863 & Potteau, Jacques-Philippe & 121 & Ohmed ben Olderramon \\
\hline 44 & 1863 & Potteau, Jacques-Philippe & 121 & Ohmed ben Olderramon \\
\hline 45 & 1863 & Potteau, Jacques-Philippe & 122 & Ziani ben Eloutani \\
\hline 46 & 1863 & Potteau, Jacques-Philippe & 122 & Ziani ben Eloutani \\
\hline 47 & 1863 & Potteau, Jacques-Philippe & 124 & Messaoud ben amar \\
\hline 48 & 1863 & Potteau, Jacques-Philippe & 124 & Messaoud ben amar \\
\hline 49 & 1863 & Potteau, Jacques-Philippe & 125 & Ahmed ben Kilgassem \\
\hline 50 & 1863 & Potteau, Jacques-Philippe & 125 & Ahmed ben Kilgassem \\
\hline 51 & 1863 & Potteau, Jacques-Philippe & 126 & Brabin ben Salah \\
\hline 52 & 1863 & Potteau, Jacques-Philippe & 126 & Brabin ben Salah \\
\hline 53 & 1863 & Potteau, Jacques-Philippe & 128 & $\begin{array}{l}\text { Mohamed au said } \\
\text { Zerouke }\end{array}$ \\
\hline 54 & 1863 & Potteau, Jacques-Philippe & 128 & $\begin{array}{l}\text { Mohamed au said } \\
\text { Zerouke }\end{array}$ \\
\hline 55 & 1863 & Potteau, Jacques-Philippe & 129 & Ben zian ben sliman \\
\hline 56 & 1863 & Potteau, Jacques-Philippe & 129 & Ben zian ben sliman \\
\hline 57 & 1863 & Potteau, Jacques-Philippe & 130 & Mohamed ben ahmed \\
\hline 58 & 1863 & Potteau, Jacques-Philippe & 130 & Mohamed ben ahmed \\
\hline 59 & 1863 & Potteau, Jacques-Philippe & 131 & Mohamed ben dris \\
\hline 60 & 1863 & Potteau, Jacques-Philippe & 131 & Mohamed ben dris \\
\hline 61 & 1863 & Potteau, Jacques-Philippe & 132 & $\begin{array}{l}\text { Abdel kader ben } \\
\text { Mohamed }\end{array}$ \\
\hline 62 & 1863 & Potteau, Jacques-Philippe & 132 & $\begin{array}{l}\text { Abdel kader ben } \\
\text { Mohamed }\end{array}$ \\
\hline 63 & 1863 & Potteau, Jacques-Philippe & 136 & Ali ben Asmar \\
\hline 64 & 1863 & Potteau, Jacques-Philippe & 136 & Ali ben Asmar \\
\hline 65 & 1863 & Potteau, Jacques-Philippe & 137 & $\begin{array}{l}\text { Ben aouda Ben } \\
\text { dedouche }\end{array}$ \\
\hline 66 & 1863 & Potteau, Jacques-Philippe & 137 & $\begin{array}{l}\text { Ben aouda Ben } \\
\text { dedouche }\end{array}$ \\
\hline 67 & 1863 & Potteau, Jacques-Philippe & 139 & Haddour Ben Abdaloz \\
\hline 68 & 1863 & Potteau, Jacques-Philippe & 139 & Haddour Ben Abdaloz \\
\hline 69 & 1863 & Potteau, Jacques-Philippe & 141 & Mohamed ben Brahim \\
\hline 70 & 1863 & Potteau, Jacques-Philippe & 142 & Phan Thong Ging \\
\hline 71 & 1863 & Potteau, Jacques-Philippe & 143 & Phan-plu-Thu \\
\hline 72 & 1863 & Potteau, Jacques-Philippe & 143 & Phan-plu-Thu \\
\hline 73 & 1863 & Potteau, Jacques-Philippe & 143 & Phan-plu-Thu \\
\hline 74 & 1863 & Potteau, Jacques-Philippe & 144 & Ngug-kai-dan \\
\hline 75 & 1863 & Potteau, Jacques-Philippe & 145 & Nguŷen bûu thân \\
\hline 76 & 1863 & Potteau, Jacques-Philippe & 145 & Nguŷen bûu thân \\
\hline 77 & 1863 & Potteau, Jacques-Philippe & 145 & Nguŷen bûu thân \\
\hline 78 & 1863 & Potteau, Jacques-Philippe & 145 & Nguŷen bûu thân \\
\hline 79 & 1863 & Potteau, Jacques-Philippe & 146 & Phan bûu do \\
\hline 80 & 1863 & Potteau, Jacques-Philippe & 146 & Phan bûu do \\
\hline 81 & 1863 & Potteau, Jacques-Philippe & 147 & Tian vân cu \\
\hline 82 & 1863 & Potteau, Jacques-Philippe & 148 & Luong van thé \\
\hline 83 & 1863 & Potteau, Jacques-Philippe & 148 & Luong van thé \\
\hline 84 & 1863 & Potteau, Jacques-Philippe & 149 & Ta hue Ké \\
\hline
\end{tabular}

Algerian Military

Algerian Military

Algerian Military

Algerian Military

Algerian Military

Algerian Military

Algerian Military

Algerian Military

Algerian Military

Algerian Military

Algerian Military

Algerian Military

Algerian Military

Algerian Military

Algerian Military

Algerian Military

Algerian Military

Algerian Military

Algerian Military

Algerian Military

Algerian Military

Algerian Military

Algerian Military

Algerian Military

Algerian Military

Algerian Military

Algerian Military

Algerian Military

Algerian Military

Algerian Military

Algerian Military

Embassy of Cochinchina

Embassy of Cochinchina

Embassy of Cochinchina

Embassy of Cochinchina

Embassy of Cochinchina

Embassy of Cochinchina

Embassy of Cochinchina

Embassy of Cochinchina

Embassy of Cochinchina

Embassy of Cochinchina

Embassy of Cochinchina

Embassy of Cochinchina

Embassy of Cochinchina

Embassy of Cochinchina

Embassy of Cochinchina 


\begin{tabular}{|c|c|c|}
\hline 85 & 1863 & Potteau, Jacques-Philippe \\
\hline 86 & 1863 & Potteau, Jacques-Philippe \\
\hline 0 & 1863 & Potteau, Jacques-Philippe \\
\hline 88 & 1863 & Potteau, Jacques-Philippe \\
\hline 89 & 1863 & Potteau, Jacques-Philippe \\
\hline 90 & 1863 & Potteau, Jacques-Philippe \\
\hline 91 & 1863 & Potteau, Jacques-Philippe \\
\hline 92 & 1863 & Potteau, Jacques-Philippe \\
\hline 93 & 1863 & Potteau, Jacques-Philippe \\
\hline 94 & 1863 & Potteau, Jacques-Philippe \\
\hline 95 & 1863 & Potteau, Jacques-Philippe \\
\hline 96 & 1863 & Potteau, Jacques-Philippe \\
\hline 97 & 1863 & Potteau, Jacques-Philippe \\
\hline 98 & 1863 & Potteau, Jacques-Philippe \\
\hline 99 & 1863 & Potteau, Jacques-Philippe \\
\hline 100 & 1863 & Potteau, Jacques-Philippe \\
\hline 101 & 1863 & Potteau, Jacques-Philippe \\
\hline 102 & 1863 & Potteau, Jacques-Philippe \\
\hline 103 & 1863 & Potteau, Jacques-Philippe \\
\hline 104 & 1863 & Potteau, Jacques-Philippe \\
\hline 105 & 1863 & Potteau, Jacques-Philippe \\
\hline 106 & 1863 & Potteau, Jacques-Philippe \\
\hline 107 & 1863 & Potteau, Jacques-Philippe \\
\hline 108 & 1863 & Potteau, Jacques-Philippe \\
\hline 109 & 1863 & Potteau, Jacques-Philippe \\
\hline 110 & 1863 & Potteau, Jacques-Philippe \\
\hline 111 & 1863 & Potteau, Jacques-Philippe \\
\hline 112 & 1863 & Potteau, Jacques-Philippe \\
\hline 113 & 1863 & Potteau, Jacques-Philippe \\
\hline 114 & 1863 & Potteau, Jacques-Philippe \\
\hline 115 & 1863 & Potteau, Jacques-Philippe \\
\hline 116 & 1863 & Potteau, Jacques-Philippe \\
\hline 117 & 1863 & Potteau, Jacques-Philippe \\
\hline 118 & 1863 & Potteau, Jacques-Philippe \\
\hline 119 & 1863 & Potteau, Jacques-Philippe \\
\hline 120 & 1863 & Potteau, Jacques-Philippe \\
\hline 121 & 1863 & Potteau, Jacques-Philippe \\
\hline 122 & 1863 & Potteau, Jacques-Philippe \\
\hline 123 & 1863 & Potteau, Jacques-Philippe \\
\hline 124 & 1863 & Potteau, Jacques-Philippe \\
\hline 125 & 1863 & Potteau, Jacques-Philippe \\
\hline 126 & 1863 & Potteau, Jacques-Philippe \\
\hline 127 & 1863 & Potteau, Jacques-Philippe \\
\hline 128 & 1863 & Potteau, Jacques-Philippe \\
\hline 129 & 1863 & Potteau, Jacques-Philippe \\
\hline 130 & 1863 & Potteau, Jacques-Philippe \\
\hline 131 & 1863 & Potteau, Jacques-Philippe \\
\hline 132 & 1863 & Potteau, Jacques-Philippe \\
\hline 133 & 1863 & Potteau, Jacques-Philippe \\
\hline 134 & 1863 & Potteau, Jacques-Philippe \\
\hline 135 & 1863 & Potteau, Jacques-Philippe \\
\hline 136 & 1863 & Potteau, Jacques-Philippe \\
\hline 137 & 1862 & Rossier, Pierre Joseph \\
\hline 138 & 1864 & Potteau, Jacques-Philip \\
\hline
\end{tabular}

149 Ta hue Ké

150 Han té

150 Han té

150 Han té

151 Hô van buãn

152 Ba-thuang

152 Ba-thuang

153 Guyĕn

154 Sen diam

154 Sen diam

154 Sen diam

155 Michel Vannier

155 Michel Vannier

156 Marie Vannier

156 Marie Vannier

156 Marie Vannier

157 Tân

157 Tân

158 Hiêp

159 Hieû

160 Clére phong

160 Clére phong

160 Clére phong

161 Pédro diêu

161 Pédro diêu

162 Dân yaü

162 Dân yaü

163 Hó

163 Hó

164 D'a

164 D'a

165 Nguŷen bûu câp

165 Nguŷen bûu câp

166 Nguŷen bûu câp

166 Nguŷen bûu câp

167 Cang

167 Cang

168 Tran-van Luong

168 Tran-van Luong

169 Simon cûa

169 Simon cûa

170 Paulus tru'ong Chânh

170 Paulus tru'ong Chânh

171 Petrus sang

171 Petrus sang

172 Hô van nbuân

173 Kieú

173 Kieú

174 Cui gian Ihenh

174 Cui gian Ihenh

177 Hiêp

177 Hiêp

181 Cochinchinoise

182 Ike-da Tsikou-go-no-
Embassy of Cochinchina Embassy of Cochinchina Embassy of Cochinchina Embassy of Cochinchina Embassy of Cochinchina Embassy of Cochinchina Embassy of Cochinchina Embassy of Cochinchina Embassy of Cochinchina Embassy of Cochinchina Embassy of Cochinchina Embassy of Cochinchina Embassy of Cochinchina Embassy of Cochinchina Embassy of Cochinchina Embassy of Cochinchina Embassy of Cochinchina Embassy of Cochinchina Embassy of Cochinchina Embassy of Cochinchina Embassy of Cochinchina Embassy of Cochinchina Embassy of Cochinchina Embassy of Cochinchina Embassy of Cochinchina Embassy of Cochinchina Embassy of Cochinchina Embassy of Cochinchina Embassy of Cochinchina Embassy of Cochinchina Embassy of Cochinchina Embassy of Cochinchina Embassy of Cochinchina Embassy of Cochinchina Embassy of Cochinchina Embassy of Cochinchina Embassy of Cochinchina Embassy of Cochinchina Embassy of Cochinchina Embassy of Cochinchina Embassy of Cochinchina Embassy of Cochinchina Embassy of Cochinchina Embassy of Cochinchina Embassy of Cochinchina Embassy of Cochinchina Embassy of Cochinchina Embassy of Cochinchina Embassy of Cochinchina Embassy of Cochinchina Embassy of Cochinchina Embassy of Cochinchina Under M. F. Bocourt Japanese Embassy 


\begin{tabular}{|c|c|c|c|c|c|}
\hline 139 & 1864 & Potteau, Jacques-Philippe & 182 & $\begin{array}{l}\text { kami } \\
\text { Ike-da Tsikou-go-no- } \\
\text { kami }\end{array}$ & Japanese Embassy \\
\hline 40 & 1864 & Potteau, Jacques-Philippe & 183 & $\begin{array}{l}\text { Kawadzou Idzou no } \\
\text { kami }\end{array}$ & Japanese Embassy \\
\hline 41 & 1864 & Potteau, Jacques-Philippe & 183 & $\begin{array}{l}\text { Kawadzou Idzou no } \\
\text { kami }\end{array}$ & Japanese Embassy \\
\hline 12 & 1864 & Potteau, Jacques-Philippe & 184 & $\begin{array}{l}\text { Kawada Sakami-no- } \\
\text { kami }\end{array}$ & Japanese Embassy \\
\hline 43 & 1864 & Potteau, Jacques-Philippe & 184 & $\begin{array}{l}\text { Kawada Sakami-no- } \\
\text { kami }\end{array}$ & Japanese Embassy \\
\hline 144 & 1864 & Potteau, Jacques-Philippe & 185 & Ta-nabé Ta-itsi & Japanese Embassy \\
\hline 145 & 1864 & Potteau, Jacques-Philippe & 185 & Ta-nabé Ta-itsi & Japanese Embassy \\
\hline 146 & 1864 & Potteau, Jacques-Philippe & 186 & Ta-naka ren-ta-rō & Japanese Embassy \\
\hline 147 & 1864 & Potteau, Jacques-Philippe & 186 & Ta-naka ren-ta-rō & Japanese Embassy \\
\hline 148 & 1864 & Potteau, Jacques-Philippe & 187 & Nisi-kitsi-zyou-rō & Japanese Embassy \\
\hline 149 & 1864 & Potteau, Jacques-Philippe & 187 & Nisi-kitsi-zyou-rō & Japanese Embassy \\
\hline 150 & 1864 & Potteau, Jacques-Philippe & 187 & Nisi-kitsi-zyou-rō & Japanese Embassy \\
\hline 151 & 1864 & Potteau, Jacques-Philippe & 188 & Sai-to-dzi-rō-ta-rō & Japanese Embassy \\
\hline 152 & 1864 & Potteau, Jacques-Philippe & 188 & Sai-to-dzi-rō-ta-rō & Japanese Embassy \\
\hline 153 & 1864 & Potteau, Jacques-Philippe & 189 & Sou-to Taki-itsi-rō & Japanese Embassy \\
\hline 154 & 1864 & Potteau, Jacques-Philippe & 189 & Sou-to Taki-itsi-rō & Japanese Embassy \\
\hline 155 & 1864 & Potteau, Jacques-Philippe & 190 & Syo-da saban-rō & Japanese Embassy \\
\hline 156 & 1864 & Potteau, Jacques-Philippe & 190 & Syo-da saban-rō & Japanese Embassy \\
\hline 157 & 1864 & Potteau, Jacques-Philippe & 191 & Fori-yé rokou-go-rō & Japanese Embassy \\
\hline 158 & 1864 & Potteau, Jacques-Philippe & 192 & Ya-tsou-kou si-ro & Japanese Embassy \\
\hline 159 & 1864 & Potteau, Jacques-Philippe & 193 & Masou-da taka-no souké & Japanese Embassy \\
\hline 160 & 1864 & Potteau, Jacques-Philippe & 193 & Masou-da taka-no souké & Japanese Embassy \\
\hline 161 & 1864 & Potteau, Jacques-Philippe & 194 & Souzi-ouza-ai-zo & Japanese Embassy \\
\hline 162 & 1864 & Potteau, Jacques-Philippe & 194 & Souzi-ouza-ai-zo & Japanese Embassy \\
\hline 163 & 1864 & Potteau, Jacques-Philippe & 195 & Matsi-nami kou-no & Japanese Embassy \\
\hline 164 & 1864 & Potteau, Jacques-Philippe & 195 & Matsi-nami kou-no & Japanese Embassy \\
\hline 165 & 1864 & Potteau, Jacques-Philippe & 196 & Ya-no riro bé-yé & Japanese Embassy \\
\hline 166 & 1864 & Potteau, Jacques-Philippe & 196 & Ya-no riro bé-yé & Japanese Embassy \\
\hline 167 & 1864 & Potteau, Jacques-Philippe & 197 & Yama-outsi & Japanese Embassy \\
\hline 168 & 1864 & Potteau, Jacques-Philippe & 198 & Seki-sin-patsi & Japanese Embassy \\
\hline 169 & 1864 & Potteau, Jacques-Philippe & 198 & Seki-sin-patsi & Japanese Embassy \\
\hline 170 & 1864 & Potteau, Jacques-Philippe & 199 & Masou-da sousoumon & Japanese Embassy \\
\hline 171 & 1864 & Potteau, Jacques-Philippe & 199 & Masou-da sousoumon & Japanese Embassy \\
\hline 172 & 1864 & Potteau, Jacques-Philippe & 200 & Fara-da go-itsi & Japanese Embassy \\
\hline 173 & 1864 & Potteau, Jacques-Philippe & 200 & Fara-da go-itsi & Japanese Embassy \\
\hline 174 & 1864 & Potteau, Jacques-Philippe & 201 & $\begin{array}{l}\text { Ko-Tozoumi yasou-yé- } \\
\text { mon }\end{array}$ & Japanese Embassy \\
\hline 175 & 1864 & Potteau, Jacques-Philippe & 201 & $\begin{array}{l}\text { Ko-Tozoumi yasou-yé- } \\
\text { mon }\end{array}$ & Japanese Embassy \\
\hline 176 & 1864 & Potteau, Jacques-Philippe & 202 & Oho-seki fan-no zouké & Japanese Embassy \\
\hline 177 & 1864 & Potteau, Jacques-Philippe & 202 & Oho-seki fan-no zouké & Japanese Embassy \\
\hline 178 & 1864 & Potteau, Jacques-Philippe & 203 & Kané-gami sa-souké & Japanese Embassy \\
\hline 179 & 1864 & Potteau, Jacques-Philippe & 203 & Kané-gami sa-souké & Japanese Embassy \\
\hline 180 & 1864 & Potteau, Jacques-Philippe & 204 & Iva-matsou Ta-ro & Japanese Embassy \\
\hline 181 & 1864 & Potteau, Jacques-Philippe & 204 & Iva-matsou Ta-ro & Japanese Embassy \\
\hline 182 & 1864 & Potteau, Jacques-Philippe & 205 & Bes-syo sad-zi-ro & Japanese Embassy \\
\hline 183 & 1864 & Potteau, Jacques-Philippe & 205 & Bes-syo sad-zi-ro & Japanese Embassy \\
\hline 184 & 1864 & Potteau, Jacques-Philippe & 206 & Takahosi Tome-sabu-rō & Japanese Embassy \\
\hline
\end{tabular}




\begin{tabular}{|c|c|c|c|c|c|}
\hline 185 & 1864 & Potteau, Jacques-Philippe & 207 & Saga-nami fisasi & Japanese Embassy \\
\hline 186 & 1864 & Potteau, Jacques-Philippe & 207 & Saga-nami fisasi & Japanese Embassy \\
\hline 187 & 1864 & Potteau, Jacques-Philippe & 208 & Tama ki san-ya & Japanese Embassy \\
\hline 188 & 1864 & Potteau, Jacques-Philippe & 208 & Tama ki san-ya & Japanese Embassy \\
\hline 189 & 1864 & Potteau, Jacques-Philippe & 209 & Mi-yaké Hidzou & Japanese Embassy \\
\hline 190 & 1864 & Potteau, Jacques-Philippe & 209 & Mi-yaké Hidzou & Japanese Embassy \\
\hline 191 & 1864 & Potteau, Jacques-Philippe & 210 & Ok kotsou watari & Japanese Embassy \\
\hline 192 & 1864 & Potteau, Jacques-Philippe & 210 & Ok kotsou watari & Japanese Embassy \\
\hline 193 & 1864 & Potteau, Jacques-Philippe & 211 & Mori-da ya-souké & Japanese Embassy \\
\hline 194 & 1864 & Potteau, Jacques-Philippe & 211 & Mori-da ya-souké & Japanese Embassy \\
\hline 195 & 1864 & Potteau, Jacques-Philippe & 212 & Oura-Moto to-ki-ro & Japanese Embassy \\
\hline 196 & 1864 & Potteau, Jacques-Philippe & 212 & Oura-Moto to-ki-ro & Japanese Embassy \\
\hline 197 & 1864 & Potteau, Jacques-Philippe & 213 & Ou-tki-da Tsu-ne sabu-rō & Other \\
\hline 198 & 1864 & Potteau, Jacques-Philippe & 213 & Ou-tki-da Tsu-ne sabu-rō & Other \\
\hline 199 & 1864 & Potteau, Jacques-Philippe & 214 & Hayasi kankai & Other \\
\hline 200 & 1865 & Potteau, Jacques-Philippe & 251 & Ahmed-Ben-Yelloub & Algerian Military \\
\hline 201 & 1865 & Potteau, Jacques-Philippe & 251 & Ahmed Ben Yelloub & Algerian Military \\
\hline 202 & 1865 & Potteau, Jacques-Philippe & 252 & Yelloub Ben Tobij & Algerian Military \\
\hline 203 & 1865 & Potteau, Jacques-Philippe & 253 & Moustapha Ben Onarga & Algerian Military \\
\hline 204 & 1865 & Potteau, Jacques-Philippe & 253 & Moustapha Ben Onarga & Algerian Military \\
\hline 205 & 1865 & Potteau, Jacques-Philippe & 257 & Mohammed Ben Oli & Algerian Military \\
\hline 206 & 1865 & Potteau, Jacques-Philippe & 257 & Mohammed Ben Onarga & Algerian Military \\
\hline 207 & 1865 & Potteau, Jacques-Philippe & 260 & L'Emir Abd-el-Kader & Other \\
\hline 208 & 1865 & Potteau, Jacques-Philippe & 260 & L'Emir Abd-el-Kader & Other \\
\hline 209 & 1865 & Potteau, Jacques-Philippe & 260 & L'Emir Abd-el-Kader & Other \\
\hline 210 & 1865 & Potteau, Jacques-Philippe & 260 & L'Emir Abd-el-Kader & Other \\
\hline 211 & 1866 & Potteau, Jacques-Philippe & 265 & Rakai Ben Bazin & Algerian Military \\
\hline 212 & 1866 & Potteau, Jacques-Philippe & 265 & Rakai Ben Bazin & Algerian Military \\
\hline 213 & 1866 & Potteau, Jacques-Philippe & 266 & Echabla Ben Ebbala & Other \\
\hline 214 & 1866 & Potteau, Jacques-Philippe & 266 & Echabla Ben Ebbala & Other \\
\hline 215 & 1866 & Potteau, Jacques-Philippe & 267 & $\begin{array}{l}\text { Abdjeia bente } \\
\text { Balguacinne }\end{array}$ & Other \\
\hline 216 & 1866 & Potteau, Jacques-Philippe & 267 & $\begin{array}{l}\text { Abdeja bente } \\
\text { Balguacinne }\end{array}$ & Other \\
\hline 217 & 1866 & Potteau, Jacques-Philippe & 268 & Li Yunne Ichiaoh & Chinese Embassy \\
\hline 218 & 1866 & Potteau, Jacques-Philippe & 268 & Li Yunne Ichiaoh & Chinese Embassy \\
\hline 219 & 1866 & Potteau, Jacques-Philippe & 269 & Ichang-yung-hion & Chinese Embassy \\
\hline 220 & 1866 & Potteau, Jacques-Philippe & 269 & Ichang-yung-hion & Chinese Embassy \\
\hline 221 & 1866 & Potteau, Jacques-Philippe & 270 & Iaé-Ichaoh-hiang & Chinese Embassy \\
\hline 222 & 1866 & Potteau, Jacques-Philippe & 271 & Lion Kunne Fung & Chinese Embassy \\
\hline 223 & 1866 & Potteau, Jacques-Philippe & 273 & $\begin{array}{l}\text { Bouguerrah ben } \\
\text { mohamed }\end{array}$ & Algerian Military \\
\hline 224 & 1866 & Potteau, Jacques-Philippe & 273 & $\begin{array}{l}\text { Bouguerrah ben } \\
\text { mohamed }\end{array}$ & Algerian Military \\
\hline 225 & 1866 & Potteau, Jacques-Philippe & 274 & Mezian Ben Saüs & Algerian Military \\
\hline 226 & 1866 & Potteau, Jacques-Philippe & 274 & Mezian Ben Saüs & Algerian Military \\
\hline 227 & 1869 & Potteau, Jacques-Philippe & 276 & Jeune japonaise & Other \\
\hline 228 & 1867 & Other & 278 & Le prince royal de Siam & Other \\
\hline 229 & 1867 & Potteau, Jacques-Philippe & 280 & Corv-aKan-ve & Other \\
\hline 230 & 1867 & Potteau, Jacques-Philippe & 280 & Corv-aKan-ve & Other \\
\hline 231 & 1867 & Potteau, Jacques-Philippe & 281 & Tcheon-ya-Mäi & Other \\
\hline 232 & 1867 & Potteau, Jacques-Philippe & 282 & Leao-ya-Tchoé & Other \\
\hline 233 & 1867 & Potteau, Jacques-Philippe & 282 & Leao-ya-Tchoé & Other \\
\hline 234 & 1867 & Potteau, Jacques-Philippe & 283 & Corv-aKan & Other \\
\hline
\end{tabular}




\begin{tabular}{l|ll}
235 & 1869 & Potteau, Jacques-Philippe \\
236 & 1869 & Potteau, Jacques-Philippe \\
237 & 1869 & Potteau, Jacques-Philippe \\
238 & 1869 & Potteau, Jacques-Philippe \\
239 & 1869 & Potteau, Jacques-Philippe \\
240 & 1869 & Potteau, Jacques-Philippe \\
241 & 1869 & Potteau, Jacques-Philippe \\
242 & 1869 & Potteau, Jacques-Philippe \\
243 & 1869 & Potteau, Jacques-Philippe \\
244 & 1869 & Potteau, Jacques-Philippe \\
245 & 1869 & Potteau, Jacques-Philippe \\
246 & 1869 & Potteau, Jacques-Philippe \\
247 & 1869 & Potteau, Jacques-Philippe \\
248 & 1869 & Potteau, Jacques-Philippe \\
249 & 1869 & Potteau, Jacques-Philippe \\
250 & 1869 & Potteau, Jacques-Philippe \\
251 & 1869 & Potteau, Jacques-Philippe \\
252 & 1869 & Potteau, Jacques-Philippe \\
253 & 1869 & Potteau, Jacques-Philippe
\end{tabular}

286 S. Exc. Sounneta Jen

287 Tzo-chu-fan

288 Lien-Lao-ge

288 Lien-Lao-ge

290 Tchang-Lao-ge

291 Ta-Moo-an

292 Wang-wen-Knay

292 Wang-wen-Knay

293 Wnang-chao-yan

293 Wnang-chao-yan

294 Koné-lien-fon

295 Chang-hoa-fang

295 Chang-hoa-fang

296 Hung-Pun-Joo

296 Hung-Pun-Joo

297 Lio-chun-chi

298 Chang-fao-fan

298 Chang-fao-fan

299 Chang-kiva-an
Chinese Embassy

Chinese Embassy

Chinese Embassy

Chinese Embassy

Chinese Embassy

Chinese Embassy

Chinese Embassy

Chinese Embassy

Chinese Embassy

Chinese Embassy

Chinese Embassy

Chinese Embassy

Chinese Embassy

Chinese Embassy

Chinese Embassy

Chinese Embassy

Chinese Embassy

Chinese Embassy

Chinese Embassy 
Aubenas, Sylvie. "Boulevard des Capucines: the Glory of the Empire." In Gustave Le Gray 1820 1884, edited by Gordon Baldwin. Los Angeles, CA: J Paul Getty Museum, 2002.

Banta, Melissa. A Timely Encounter: Nineteenth Century Photographs of Japan. Cambridge, MA: Peabody Museum Press, 1988.

Banta, Melissa. From Site to Sight: Anthropology, Photography, and the Power of Imagery. Cambridge, MA: Peabody Museum Press, 1986.

Barthe, Christine. "Des photographies dites <<ethnographiques >>” In D'un regard l'autre: Photographies XIXe siècle, 159-171. Paris: Musée du quai Branly and Arles: Actes Sud, 2006.

Barthe, Christine. "Models \& Norms: the Relationship between Ethnographic Photographs and Sculptures." In Facing the Other: Charles Cordier (1827-1905) Ethnographic Sculptor, 93111. New York, NY: Harry N Abrams, 2004.

Bennet, Terry, Bourgarel, Gérard and David Collin. Pierre Joseph Rossier, Photographe: une mémoire retrouvée. Fribourg, Switzerland: Pro Fribourg, 2006.

Braun, Marta. "Aux Limites du Savoir: la photographie et les sciences de l'observation" in L'Art de la photographie des origines à nos jours, edited by André Gunthert and Michel Poivert, 140-177. Paris: éditions Citadelles-Mazenod, 2007.

Braun, Marta. "China, 1854" In Musée du quai Branly: the Collection: Art from Africa, Asia, Oceania, and the Americas, edited by Yves Le Fur, 392. Paris: Flammarion, 2009.

Darwin, Charles. "Chapter VII: On the Races of Man." In Descent of Man and Selection Relating to Sex. New York, NY: AMS Press, 1972.

Edwards, Elizabeth, ed. Anthropology and Photography 1860-1920. New Haven, CT: Yale University Press, 1992.

Edwards, Elizabeth. Raw Histories: Photographs, Anthropology and Museums. Oxford: Berg, 2006.

Edwards, Elizabeth. "Ordering Others: Photography, Anthropologies and Taxonomies." In In Visible Light: Photography and Classification in Art, Science and The Everyday, edited by Chrissie Iles and Russell Roberts, 54-68. Oxford: Museum of Modern Art, 1997.

Edwards, Elizabeth. "Photographic 'Types': The Pursuit of Method," Visual Anthropology 3, nos. 2-3 (1990): 235-58.

Frizot, Michel. "Body of Evidence: The Enthnophotography of Difference." In A New History of Photography, edited by Michel Frizot, 259-271. Cologne: Könemann, 1998.

Grinshaw, Anna. The Ethnographer's Eye: Ways of Seeing in Anthropology. Cambridge and New York, NY: Cambridge University Press, 2001. 
Jehel, Pierre-Jérome. Photographie et anthropologie en France au XIXe siècle. Mémoire de DEA sous la direction d'André Rouillé et Sylvain Maresca, Université Paris VIII, 1995.

McCauley, Elizabeth Anne. Industrial Madness: Commercial Photography in Paris, 1848-1871. New Haven, CT: Yale University Press, 1994.

McCauley, Elizabeth Anne. Likenesses: Portrait Photography in Europe, 1850-1870. Albuquerque, NM: University of New Mexico Press, 1980.

Pinney, Christopher. "The Parallel Histories of Anthropology \& Photography." In Anthropology \& Photography 1860-1920, edited by Elizabeth Edwards. New Haven, CT: Yale University Press, 1992.

Pinney, Christopher and Nicolas Peterson, editors. Photography's Other Histories. Durham, NC: Duke University Press, 2003.

Scherer, Joanna C. "The Photographic Document: photographs as primary data in Anthropological enquiry. In Elizabeth Edwards ed. Anthropology \& Photography 1860 1920. New Haven, CT: Yale University Press, 1992.

Staum, Martin S. Labeling People: French Scholars on Race, Society and Empire, 1815-1848. Montreal, QC: McGill-Queens University Press, 2003.

\section{Internet Sources}

Bibliothèque nationale de France, Catalogues et bibliothèque numérique, $\mathrm{BnF}$ catalogue général. http://catalogue.bnf.fr.

Bloomsbury Auctions London, Sales Archive. http://www.bloomsburyauctions.com.

Getty Research Institute, The, Conducting Research, Data Standards and Guidelines, "Categories for the Description of Works of Art," http://www.getty.edu/research/conducting_research/standards/cdwa/.

Harvard College Library, Tozzer Library. http://hcl.harvard.edu/libraries/tozzer/.

Musée du Quai Branly, The Iconothèque Catalogue. http://www.quaibranly.fr/en/.

Peabody Museum of Archaeology \& Ethnology at Harvard University. http://www.peabody.harvard.edu/.

Pitt Rivers Museum of Anthropology and World Archaeology, University of Oxford, Object \& Photograph Collections Catalogue. http://www.prm.ox.ac.uk/.

Taylor, Roger. “Photographic Exhibitions in Britain 1839 -1865” http://peib.dmu.ac.uk/.

Vaucher, Andréa R. "A New Focus" France Magazine 66, (Summer 2003), http://www.francemagazine.org/articles/issue66/article68.asp?issue_id=66\&article_id=6 8. 